\title{
An Evaluation of Groundwater Vulnerability Assessment Methods in a Rapidly Urbanizing City: Evidence From Dakar, Senegal
}

\section{Abdoulaye Pouye ( $\nabla$ abdoulaye8.pouye@ucad.edu.sn )}

Cheikh Anta Diop University of Dakar: Universite Cheikh Anta Diop de Dakar

\section{Seynabou Cissé Faye}

Cheikh Anta Diop University of Dakar: Universite Cheikh Anta Diop de Dakar

Mathias Diedhiou

Cheikh Anta Diop University of Dakar: Universite Cheikh Anta Diop de Dakar

Cheikh Becaye Gaye

Cheikh Anta Diop University of Dakar: Universite Cheikh Anta Diop de Dakar

Richard G. Taylor

University College London

\section{Research Article}

Keywords: urban, groundwater quality, vulnerability, vadose zone, GIS-based indices

Posted Date: November 9th, 2021

DOI: https://doi.org/10.21203/rs.3.rs-785867/v1

License: (c) (i) This work is licensed under a Creative Commons Attribution 4.0 International License.

Read Full License 
1 An evaluation of groundwater vulnerability assessment methods in 2 a rapidly urbanizing city: evidence from Dakar, Senegal

Abdoulaye Pouye ${ }^{1}$, Seynabou Cissé Faye ${ }^{1}$, Mathias Diedhiou ${ }^{1}$, Cheikh Becaye Gaye ${ }^{1}$, Richard G. Taylor ${ }^{2}$

${ }^{\text {I} G e o l o g y ~ D e p a r t m e n t, ~ F a c u l t y ~ o f ~ S c i e n c e s ~ a n d ~ T e c h n i q u e s, ~ U n i v e r s i t y ~ C h e i k h ~ A n t a ~ D i o p, ~ D a k a r, ~ B . P . ~ 5005, ~}$ Dakar-Fann, Senegal

${ }^{2}$ Department of Geography University College London (UCL) Gower Street

London WC1E 6BTUnited Kingdom

Phone: +221 7740203 65/+221 7720235 01/+221 7795948 32/ +44 (0) 2076790591

9 Email: abdoulaye8.pouye@ucad.edu.sn / seynaboucissefay@gmail.com / mathias.diedhiou@ucad.edu.sn

10 /cheikhbecayegaye@gmail.com / richard.taylor@ucl.ac.uk

Abstract:

In rapidly growing cities in the tropics, unregulated urban development presents a major risk to groundwater quality. Here, we assess the vulnerability of an unconfined aquifer of Quaternary sands in the Thiaroye area of Dakar (Senegal) to contamination using four GIS-based indices (DRASTIC, DRASTIC_N, SINTACS, SI). Our correlation of assessed vulnerability to observed impact is semi-quantitative, relating observed groundwater quality, based on nitrate concentrations and tryptophan-like fluorescence to vulnerability degrees (i.e. coincidence rates). We show that considerably more of the Thiaroye area has a "very high vulnerability" according to SI (36\%) relative to DRASTIC (5\%) and SINTACS (9\%); "high vulnerability" is estimated using DRASTIC_N (100\%), DRASTIC (66\%) and SINTACS (69\%). Single-parameter sensitivity tests show that groundwater depth, soil, topography, land use and redox parameters strongly influence assessments of groundwater vulnerability. Correlation with observed nitrate concentrations reveals aquifer vulnerability is better represented by SI (coincidence rates of 56\%) relative to DRASTIC_N (43\%), SINTACS (38\%) and DRASTIC (34\%). The underestimation of groundwater vulnerability in Dakar using DRASTIC,DRASTIC_N and SINTACS is attributed to their reliance on an assumed capacity of the unsaturated zone to attenuate surface or near-surface contaminant loading, which in the low-income (Thiaroye) area of Dakar is thin and affords limited protection. The inclusion of a land-use parameter in SI improves the characterization of groundwater vulnerability in this low-income, rapidly urbanizing area of Dakar.

Key words: urban, groundwater quality, vulnerability, vadose zone, GIS-based indices 
Groundwater resources in drylands are often the only perennial source of freshwater to meet domestic, agricultural and industrial demands. Tropical drylands are often characterized by limited, seasonal surface water availability that is a function of their climate. The greater vulnerability of surface water to pollution is also an obstacle to its sustainable use. Use of shallow groundwater for drinking and other domestic purposes is an especially common feature of many urban low-income communities (Howard et al., 2003; Gaye and Tindimugaya, 2019). Urban groundwater use includes not only utility withdrawals but also private self-supply for residential, commercial, industrial, and agricultural uses (Foster et al., 2018). Urban self-supply of water and direct use of local wells by low-income households is often of vital importance to a large proportion of a city's inhabitants (Grönwall et al., 2010).

Vulnerability assessments are commonly conducted in areas where water resources are stressed due to anthropogenic activities (Singh et al., 2015). Groundwater vulnerability assessment studies have, to date, shown urban areas to be increasingly prone to groundwater contamination (NRC, 1993; Alam et al., 2012; Singh et al., 2015). Three primary methods exist by which groundwater vulnerability is commonly assessed: 1) a subjective overlay and index method based on the rating of individual hydrogeological factors (Kumar et al., 2016); 2) process-based mathematical models that are data intensive (Pradhan et al., 2013); and 3) statistical models that describe the contamination potential for a specified geographical region using the available data in the regions of interest (NRC, 1993; Kumar et al., 2015). The subjective overlay and index method is the simplest and most widely used method in Sub-Saharan Africa where the availability of hydrogeological data is commonly limited (Oke and Fourie, 2017). Among the different overlay and index methods, DRASTIC is one of the most popular due to its performance and ease of use (Barbulescu, 2020). In the last two decades, DRASTIC has been employed in several studies to assess groundwater vulnerability in Asia (Babiker et al., 2005; Yin et al., 2011; Ghosh et al., 2015), Africa (Jourda et al., 2007; Saidi et al., 2009; Hamza et al., 2008, 2010; Neh et al., 2014; Oke, 2020), and the Americas (Klug, 2009; Ferral et al., 2014; Agyemang and Beauty, 2017). DRASTIC does not, however, explicitly consider spatial variability in anthropogenic factors that may be of critical importance in rapidly urbanizing, lowincome areas (Singh et al., 2015). Modifications to DRASTIC have been developed to explicitly represent groundwater vulnerability to anthropogenic pollution from surface/sub-surface sources. SINTACS (Civita et al., 1997), DRASTIC_N (Voutchkova et al., 2020) and the Susceptibility Index or SI (Riberio et al., 2000) are examples of these, which have demonstrated efficacy in assessing groundwater vulnerability in many environments (Batista S, 2004; Frances et al., 2002; Lobbo-Ferreira et Oliveira, 2005; Stigter et al., 2006 ; Hamza et al., 2008 ; Ake et al., 2010 ; Afonso et al., 2016 ; Ribeiro et al., 2016 ; Batchi et al., 2017 ; Si et al, 2017 ; Armanuos et al., 2019 ; Marjuanto et al., 2019 ; Voutchkova et al., 2020).

In Dakar (Senegal), water supply is provided by: 1) surface water via a pipeline from Lake Guiers $250 \mathrm{~km}$ away (Fig. 1) representing 50\% of the drinking water supply; and 2) groundwater from local aquifers -that include deep Maastrichtian sands, Paleocene limestones and infrabasaltic/northern coastal Quaternary sands. Despite this conjunctive use of groundwater surface water, the city faces a chronic shortage of drinking water. In densely populated, low-income areas of Thiaroye in Dakar for example, self-supply of water via dug wells as well as hand pumps is common to adapt to limitations in access to piped water supplies. Use of urban groundwater is, nonetheless, compromised by declining groundwater quality, primarily as a consequence of effluent from on-site sanitation systems (Cisse Faye et al., 2019; Diaw et al., 2020). Due to the importance of urban groundwater in the 
provision of safe water in pursuit of UN Sustainable Development Goal 6 (access to safe water for all by 2030), knowledge of effective tools to identify areas at risk of groundwater contamination, especially when monitoring is limited, is vital.

Extensive nitrate pollution in the unconfined aquifer of Quaternary sands in Dakar (Thiaroye) has been revealed by previous studies (e.g. Tandia, 2000; Cissé Faye, 2001; 2019; Diedhiou et al., 2012; Diaw et al., 2020). The high concentrations of nitrate have prompted earlier assessments of the vulnerability of shallow groundwater to contamination from its urban environment by Cisse Faye, (2001) and Madioune et al., (2005 and 2011) using DRASTIC (Aller et al., 1987) and GOD (Foster et al., 1987) assessment methods. These studies provided an overview of the areas of vulnerability of the Thiaroye groundwater to nitrate pollution at the regional scale. These methods did not, however, consider directly the impact of human activities on groundwater quality. Further, assessed vulnerabilities were not explicitly reconciled to observed groundwater contamination. This study evaluates the ability of DRASTIC, DRASTIC_N, SINTACS and SI models to assess the vulnerability of an unconfined aquifer comprising well-sorted Quaternary sands to contamination in a rapidly urbanizing environment. Here, we: 1) assess urban groundwater vulnerability using DRASTIC, DRASTIC_N, SINTACS and SI; and 2) evaluate the respective performance of these models to predict urban groundwater contamination. The ultimate goal is to inform pragmatic assessments of groundwater vulnerability in urban areas of Sub-Saharan Africa where there is commonly strong dependence on the use of on-site sanitation.

\section{Study area of Dakar (Senegal):}

Dakar is a typical fast-growing metropolitan city in Sub-Saharan Africa. Its population has increased five-fold from 583 000 inhabitants in 1971 to 3.1 million inhabitants in 2013. The population in the suburban areas (e.g. Thiaroye, Pikine, Guediawaye, Parcelles assainies, Keur Massar and Rufisque districts) is estimated at 1500000 with a mean population density of 9335 inhabitants per $\mathrm{km}^{2}$. The study area is characterized by great speed of urbanization that started after the drought that began in the Sahel in the 70s (Fig. 2a). It led urban growth-associated rapid expansion of peri-urban and unplanned settlements (Sow, 2009).

The study area focuses low-income communities served by on-site sanitation (septic tanks) within the Thiaroye watershed in the Dakar region. It is located at the collar of the peninsula with an area of $60.4 \mathrm{~km}^{2}$ (Fig. 2b). The relief is materialized by depressed dunes where three hydrogeological units are identified: the lakes area to the north, the Niayes area or closed dune depressions to the west and the dunes area which covers most of the basin. The climate is semi-arid with mean annual precipitation ranging between 450 and $500 \mathrm{~mm}$ (primarily during the rainy season between July and October) and temperatures between 21 and $29{ }^{\circ} \mathrm{C}$ (Diedhiou et al., 2012).

The study area is underlain by a Quaternary sand aquifer system which extends along the Senegal northern coastal zone from Dakar. The aquifer system itself is underlain by Eocene marl to clay formations which outcrop in the south. Quaternary deposits constitute the aquifer reservoir and comprise mainly unconsolidated clayey sands, coarse sands, eolian sands which form the Ogolian dunes in the coastal band. The aquifer is unconfined throughout the study area. Recharge is thought to occur primarily by the direct infiltration of rainfall (i.e. diffuse recharge) but also via contributions from other sources such as wastewater and irrigation waters that contaminate the groundwater (Diedhiou et al., 2012, Diouf et al., 2012, Cisse Faye et al., 2019). 


\section{Materials and methods:}

To assess groundwater vulnerability to pollution at a watershed scale in Dakar, four indices (DRASTIC, DRASTIC_N, SINTACS and SI) were considered. These models estimate the vulnerability of groundwater to contamination and it is expressed in the form of vulnerability map (Kumar et al., 2016).

\subsection{DRASTIC method:}

DRASTIC is an empirical model that estimates groundwater vulnerability in aquifer systems based on in-situ hydrogeological information (Aller et al., 1987). It is widely used to assess the intrinsic vulnerability of groundwater to a wide range of potential pollutants (Al-Abadi et al., 2014). DRASTIC assesses groundwater vulnerability to contaminants generated by human activities. It considers geological, hydrological and hydrogeological characteristics but not those of pollutant characteristics or human activities (Hamza et al., 2010). The acronym DRASTIC designates the parameters included in the method: groundwater depth (D), net recharge $(\mathrm{R})$, aquifer lithology (A), soil type (S), topography (T), impact of the unsaturated zone (I) and hydraulic conductivity $(\mathrm{C})$. The seven parameters reflect factors pertaining to the hydrogeological system that influence contaminant transport and attenuation processes. The degree of influence of each parameter is quantified by a numerical value called parametric weight, between 1 and 5 (Table 1). Each parameter is listed in classes associated with ranges from 1 to 10 . The smaller score the conditions of lower vulnerability to contamination. A numerical value referred to as the DRASTIC vulnerability index (DI) is computed by aggregating the products of the ranges by the weights of the corresponding parameters in equation 1 :

$\mathbf{D I}=\left(\mathbf{D}_{\mathbf{w}} \times \mathbf{D}_{\mathbf{r}}\right)+\left(\mathbf{R}_{\mathbf{w}} \times \mathbf{R}_{\mathbf{r}}\right)+\left(\mathbf{A}_{\mathbf{w}} \times \mathbf{A}_{\mathbf{r}}\right)+\left(\mathbf{S}_{\mathbf{w}} \times \mathbf{S}_{\mathbf{r}}\right)+\left(\mathbf{T}_{\mathbf{w}} \times \mathbf{T}_{\mathbf{r}}\right)+\left(\mathbf{I}_{\mathbf{w}} \times \mathbf{I}_{\mathbf{r}}\right)+\left(\mathbf{C}_{\mathbf{w}} \times \mathbf{C}_{\mathbf{r}}\right)(\mathbf{e q .} \mathbf{1})$ where DI is the vulnerability index, D, R, A, S, T, I, and C comprise the seven parameters of the DRASTIC method, and the subscript " $w$ " refers to the weight of the parameter and " $r$ " to its associated rating.There are seven classes, each corresponding to different degrees of vulnerability (Table 2).

\subsection{SINTACS method:}

SINTACS (Civita and De Miao, 1997) is the Italian version of the DRASTIC model. It takes into consideration the same parameters with different weights and dimensions. The acronym SINTACS stands for the initials of the following seven factors: Groundwater depth $(\mathrm{S}=$ Soggiacenzia), Net recharge ( $\mathrm{I}=$ Infiltrazione), Impact of the unsaturated zone ( $\mathrm{N}=$ effecto di autoepurazione del non-saturo), Type of soil ( $\mathrm{T}=$ Typologia della copertura), Lithology of the aquifer ( $\mathrm{A}=$ caratteristiche idrogeologische dell'acquifero), Hydraulic conductivity $(\mathrm{C}=$ conductibilità dell'acquifero) and Topography ( $\mathrm{S}=$ l'acclivita della superficie topografia). Unlike DRASTIC, SINTACS allows for weighting factors to vary spatially. Five possible scenarios are distinguished:

"Normal impact" scenario for unconsolidated sediment aquifers where water table is not deep $(<10 \mathrm{~m}$ below ground). The areas related to this scenario correspond to stable regions, in terms of land use, with or without cultivated land, low use of pesticides, fertilizers and irrigation, and widely dispersed urban areas;

$>$ "Severe Impact" scenario which corresponds to the same aquifer type subject to intensive land use, with a considerable use of pesticides, fertilizers and irrigation, dense industrial and urban settlements, liquid and solid waste deposits;

"Significant Drainage from a Surface System" scenario for areas with high infiltration to the aquifer from a surface water system; 
"Very karstified terrain" scenario;

$>$ "Fractured terrain" scenario.

The dominant scenario of the hydrogeological conditions in the study area is "Severe Impact". SINTACS is calculated similarly to DRASTIC. Weights assigned to the different parameters in the different SINTACS versions as well as vulnerability classes are presented in Tables 3 and 4.

\subsection{Susceptibility Index (SI) method:}

SI is a simplified version of the DRASTIC method and developed in Portugal by Ribeiro (2000). It is used to assess vertical specific vulnerability to anthropogenic pollution (Hamza et al., 2010). The term specific vulnerability is used to define the vulnerability of aquifer by a particular contaminant or group of contaminants. The method also considers properties of potential contaminants and their relationship to the different components of intrinsic vulnerability. It employs five parameters. The first four are identical to that used in the DRASTIC method: groundwater depth (D), net recharge (R), aquifer lithology (A) and topography (T). The fifth parameter (OS) is the translation of human activities through land use. Land cover classes have ranges from 0 to 100 (Table 5). The CORINNE Land Cover classification (European Community, 1993) has been used to classify the land use type. The susceptibility index is calculated by equation 2 :

$S I=\left(D_{\mathbf{w}} \times \mathbf{D}_{\mathbf{r}}\right)+\left(\mathbf{R}_{\mathbf{w}} \times \mathbf{R}_{\mathbf{r}}\right)+\left(\mathbf{A}_{\mathbf{w}} \times \mathbf{A}_{\mathbf{r}}\right)+\left(\mathbf{T}_{\mathbf{w}} \times \mathbf{T}_{\mathbf{r}}\right)+\left(\mathbf{O S} \mathbf{S}_{\mathbf{w}} \times \mathbf{O S} \mathbf{S}_{\mathbf{r}}\right)$

(eq. 2)

The SI method presents four vulnerability degrees according to the indices values obtained (Tables 6 and 7).

\subsection{DRASTIC_N method:}

DRASTIC_N is an extension of the DRASTIC model proposed by Voutchkova et al. (2020) that considers nitrate-specific groundwater vulnerability through the inclusion of a parameter representing the redox potential of the aquifer. This approach recognizes explicitly that the vulnerability of groundwater to nitrate contamination is influenced by the potential for denitrification to take place, converting nitrogen in nitrate to a chemically reduced form (e.g. aqueous $\mathrm{NO}_{2}{ }^{-}$, or $\mathrm{NH}_{4}{ }^{+}$or gaseous $\mathrm{N}_{2}$ or $\mathrm{NH}_{3}$ ). The new $\mathrm{N}$-parameter infers redox conditions in terms of a sampling depth above or below the interface between oxic and anoxic conditions in the saturated zone. DRASTIC_N is computed according to equation 3:

\section{DRASTIC $_{\mathrm{N}}=$ DRASTIC $+N_{W} \mathrm{~N}_{R}$}

where $\mathrm{N}_{\mathrm{R}}$ and $\mathrm{N}_{\mathrm{W}}$ are the rating and the weight for the additional parameter $\mathrm{N}$. According to Voutchkova et al. (2020), a high nitrate pollution potential (rating 10) is assigned where oxic conditions restricting denitrification occur. A medium nitrate pollution potential (rating 5) is assigned to sampling depths that reside within $\pm 5 \mathrm{~m}$ of the interface between oxic and anoxic conditions; a low nitrate pollution potential (rating 1) is assigned to sampling greater than $5 \mathrm{~m}$ below the oxic/anoxic interface.

\subsection{Single-parameter sensitivity analysis of each vulnerability assessment:}

A single-parameter sensitivity analysis was used to assess the influence of each of the different model parameters on the vulnerability measure. In this analysis, the actual or effective weight of each parameter is 
compared with the assigned or theoretical weight. The effective weight of a parameter is calculated using equation 4:

$$
W=\frac{\text { Pr. Pw }}{\mathrm{V}} \cdot 100
$$

where $\mathrm{W}$ is the effective weight of the parameter in one polygon, Pr and Pw are respectively the weight and the range of this parameter and $\mathrm{V}$ the total vulnerability index.

\subsection{Input data:}

Assessment of groundwater vulnerability requires the use of reliable data. Bibliographic research and field measurements were used to acquire information on hydrogeological characteristics in the study area. Table 8 shows the input data used. All amassed data were processed in ArcGIS (v. 10.2.2) for cartographic analyses and ERDAS Imagine for satellite image processing. The model builder tool in ArcGIS enabled computation of raw data in order to obtain the various vulnerability maps according to a methodological approach described in the diagram below.

\subsubsection{Groundwater depth:}

Depth to groundwater from the surface determines the thickness of the unsaturated zone through which infiltrating water must pass before reaching the water table in the Thiaroye aquifer. This parameter therefore influences the degree, extent, attenuation and degradation processes of the pollutant. Data were acquired by 33 field measurements made in April 2017. This dry season period is characterized by the deepest groundwater levels. The point data collected were then spatialized by interpolation using the inverse weighted distance (IDW). The results closest to reality were obtained using high power squared. The recorded errors vary from -1 to 1 metre at an RMSE of 0.5 metre.

\subsubsection{Net recharge:}

Net recharge is the amount of water infiltrated per unit area that reaches the water table (Aller et al., 1987). This parameter is involved in the vertical transport of pollutant from the soil surface to the capillary fringe. It also controls the amount of water available for dispersion and dilution of solutes in the unsaturated zone. Recharge assessment in the study area has been extensively studied. Many approaches such as basic water balance calculations (Martin, 1970; Cisse Faye., 2001), groundwater modelling (Cisse Faye, 2001; Comte et al., 2012) chloride mass balance (Diouf et al., 2012), water table fluctuations (Diouf et al., 2018; Diongue, 2018; Cisse Faye et al., 2019) have been used to assess quantitatively groundwater recharge by precipitation (Table 9). The net recharge assessment in this study is based on Comte et al. (2012) and Antea Senagrosol (2003) in which mean net recharge is computed by subtracting direct evaporation from the shallow water table (Comte et al., 2012) from mean maximum recharge, estimated at $450 \mathrm{~mm}$ in urbanized areas and $200 \mathrm{~mm}$ in the non-urbanized areas (Martin, 1970, Vallet, 1972, Antea-Senagrosol, 2003). Recharge values were determined based on depths to the water table recorded in April 2017. Strong similarities were observed between the net recharge values obtained and those estimated by the WTF method of Cuthbert et al. (2019). The recharge map was then computed by IDW interpolation from each point (error from 4 to $7 \mathrm{~cm}$ and the RMSE is $2.4 \mathrm{~cm}$ ). 


\subsubsection{Aquifer lithology:}

This parameter refers to the geological characteristics of the aquifer. The data were extracted from Cisse Faye, 2001 and Madioune et al., 2011, which relied on stratigraphic logs, drilling, boreholes and piezometers, lithological sections and the geological map of the Thiaroye aquifer to describe lithological characteristics of the aquifer.

\subsubsection{Soil type:}

Soil type data from Maignien (1959) were used to determine soil typology. The description of the different units was based on granulometric and textural soil analyses. Soil texture data were obtained from the FAO World Soil Harmonized Database.

\subsubsection{Topography:}

The study area topography is obtained from the digital elevation model covering the study area. The model was downloaded from the USGS website. The slope (\%) was then calculated using the spatial analysis tool in ARCGIS 10.2.2.

\subsubsection{Impact on the vadose zone:}

The vadose zone (unsaturated zone) is the unsaturated part of an aquifer above the water table. It is an important variable in the estimation of vulnerability, because it influences the residence time of pollutants and hence the attenuation probability. Unsaturated zone thematic map was based on the sandy facies predominating over clayey sands (Madioune et al., 2011). Unsaturated zone facies are therefore identified according to their degree of confinement

\subsubsection{Hydraulic conductivity:}

The hydraulic conductivity thematic map was derived from point data obtained by pumping tests (Geohydraulique, 1972). This information was then converted into raster data by digital interpolation using the IDW interpolation.

\subsubsection{Landuse:}

To determine land cover classes, a Landsat 8 OLI/TIRS image (scene 205 - 50) from April 03, 2017 was acquired and uploaded to the USGS database. Supervised classification was then performed with the ERDAS Imagine (v. 2014) software to obtain a land use matrix file. The employed method of classification is Corine Land Cover (European Community, 1993). Seven land use classes were observed: built, coastal dunes, surface water, vegetation, wetland, vegetable garden and landfill.

\subsubsection{Redox state of the aquifer $(N)$ :}

The nitrate reduction capacity incorporated in DRASTIC_N was estimated from a redox water type characterisation and depth-dependent nitrate reduction capacity outlined in Voutchkova et al. (2020). Analysis of sediment logs and groundwater chemical speciation $\left(\mathrm{O}_{2}, \mathrm{NO}_{3}^{-}, \mathrm{Fe}^{2+}\right.$ and $\left.\mathrm{SO}_{4}^{2-}\right)$, which control and reflect denitrification capacity, was done to assess the position of the redox interface between oxic and anoxic conditions. The predominance of sandy facies and chemically oxidised species in solution (i.e. $\mathrm{NO}_{3}^{-}$, dissolved $\mathrm{O}_{2}$ and $\mathrm{SO}_{4}{ }^{2-}$ ) 
confirm low denitrification capacity of the sampled shallow aquifer; a maximum rating of 10, reflecting a high nitrate pollution potential was therefore assigned to this parameter.

\subsection{Groundwater quality data to test vulnerability assessments}

To test the outcomes of aquifer vulnerability assessments, groundwater quality data that specifically relate to human activity were employed and included nitrate and fluorescent natural organic matter, tryptophan-like fluorescence (TLF) which describes fluorescence occurring from a range of compounds within the excitationemission wavelengths associated with the fluorescence peak of the amino acid tryptophan (Baker et al., 2002). TLF data, expressed in ppb was recently used as an indicator of faecal pollution in the Thiaroye area of Dakar (Sorensen et al., 2020).._These elements were chosen as specific contaminants to conduct a correlative analysis with the vulnerability index on the one hand and to assess the groundwater reduction capacity on the other hand. Nitrates were monitored from 2016 to 2020 in 40 groundwater samples whereas TLF were observed during 2018 from 73 groundwater samples. For the reduction capacity assessment of the aquifer, sulphate and dissolved oxygen were monitored from 2018 to 2020 on 40 samples whereas total iron data were available for 28 samples collected in 2020 (Table 10).

\section{Results:}

\subsection{Vulnerability assessment:}

Four vulnerability maps applying DRASTIC, DRASTIC_N, SINTACS and SI models were generated (Fig. 5). Computed vulnerability indices are subdivided into three classes (moderate, high, and very high). The "very high vulnerability" class is more prevalent applying SI (36\%) compared to DRASTIC and SINTACS (5\% and 9\%, respectively). In contrast, the "high vulnerability" class is more commonly computed in DRASTIC_N, DRASTIC and SINTACS $(100 \%, 65 \%$ and $69 \%$ respectively) relative to SI $(45 \%)$.

DRASTIC vulnerability indices range from 129 to 188 . "Moderate vulnerability" occurs in $30 \%$ of the study area $\left(17.5 \mathrm{~km}^{2}\right)$ and corresponds to a depression occupied by lakes to the north-east, the zone of the Niayes de Pikine to the west, and part of the southern zone at Thiaroye (Fig. 5a). These areas are characterized by a lower recharge rate and a generally sandy reservoir. "High vulnerability" is computed for $65 \%$ of the study area (39.7 $\mathrm{km}^{2}$ ) and primarily located in the western agglomeration zone as well as, in part, to the south. The relatively shallow depth to groundwater, sandy soil texture, and high recharge rates explain the computation of this "high vulnerability". "Very high vulnerability" is computed for only a small fraction (5\%) of the study area, specifically located to the west in the agglomeration zone in the counties of Pikine and Thiaroye. It is also found to the south and southeast of the study area (South Thiaroye, Mbao, Yeumbeul and Keur Massar). A single parameter sensitivity analysis (Table 11) reveals that depth to groundwater, soil type, and topography are the primary factors that influence the class of vulnerability index with actual weight $(29 \%, 11 \%$ and $6 \%)$ greater than their respective default weight $(22 \%, 9 \%$ and $4 \%)$. The net recharge, the characteristics of the aquifer, and the impact of the unsaturated zone have comparatively less influence on the computed vulnerability index with average effective weights slightly lower than their default weights. As for the hydraulic conductivity, its influence is lower with an effective weight of 5\% clearly lower than its default weight (13\%). 
Similar to DRASTIC, SINTACS vulnerability index values, which range from 136 to 221 have been grouped into three classes (Fig. 5b). "Moderate" vulnerability index occupies 22\% of the study area $\left(13 \mathrm{~km}^{2}\right)$ and corresponds to the Niayes area (Pikine) to the west, lakes along the northern coast and part of south Yeumbeul in the center. The "high" vulnerability index is observed over $69 \%\left(41.5 \mathrm{~km}^{2}\right)$ of the study area and mainly characterizes the agglomeration zone The "very high" vulnerability index of $9 \%\left(5.4 \mathrm{~km}^{2}\right)$ is mainly found in the urban area (Thiaroye, north Pikine, , Mbao, Keur Massar and north Yeumbeul). The sensitivity analysis shows that SINTACS computes similar trends to DRASTIC. Indeed, the most sensitive parameters are depth (24\%), soil $(22 \%)$ and topography (10\%). The other parameters have less influence with effective weight values lower than the theoretical weights. The hydraulic conductivity is the parameter with the least influence on the vulnerability assessment $(3 \%)$.

Susceptibility Index (SI) values range from 56 to 90 and three classes were identified. Moderate susceptibility mainly characterizes the lakes area to the north and the Niayes of Pikine with a total coverage of $11.2 \mathrm{~km}^{2}(19 \%)$ of the mapped area. The high susceptibility index occupies $45 \%$ of the study area $\left(27 \mathrm{~km}^{2}\right)$ but is concentrated in southern and eastern areas of the study area (Fig. 5c). A "very high" susceptibility index mainly characterizes the western zone with a total coverage of $21.5 \mathrm{~km}^{2}$ (36\%) of the mapped area. It is also found locally in the areas of Mbao, north Yeumbeul, Keur Massar and Malika. Single parameter sensitivity analysis shows the SI index is influenced mainly by depth and topography with values respectively $23 \%$ and $16 \%$ higher than their theoretical weight. The other parameters (aquifer characteristics and land cover) have lower specific weights, and therefore less marked influence.

For DRASTIC_N, the vulnerability indices range from 159 to 238. The "high vulnerability" class was computed throughout the study area (Fig. 5d). Variations in the index show that highest values occur in the agglomeration areas of Thiaroye, Diamaguene, Mbao and Keur Massar; lowest values are observed in the northern lake area. The sensitivity analysis shows DRASTIC_N to be influenced by depth, soil, topography and redox state of the aquifer. The other parameters (aquifer characteristics, impact of the vadose zone and hydraulic conductivity) are of lower sensitivity.

\subsection{Evaluation of vulnerability analyses:}

Comparison of the vulnerability maps shows substantial differences in assessed vulnerability. Indeed, the "very high" degree of vulnerability is greatest in the SI method (36\%) relative to DRASTIC and SINTACS. A "high" vulnerability class is predominantly assigned using DRASTIC_N, DRASTIC and SINTACS methods. Table 12 highlights the degree of vulnerability of the different methods according to the occupancy rate. The semiquantitative analysis of the correlation between these concentrations and the vulnerability categories are presented in box-plots (Fig. 6). The relationships between assessed groundwater vulnerability and observed groundwater quality range considerable (Figs. 6 and 8). We consider comparisons for nitrate first and then TLF.

For nitrate concentrations, DRASTIC shows $88 \%$ of samples $\left(\mathrm{n}=35\right.$ with $\mathrm{NO}_{3}{ }^{-}$from $\left.69-599 \mathrm{mg} / \mathrm{L}\right)$ are correlated with the "high" vulnerability. The first quartile varies from $69-224 \mathrm{mg} / \mathrm{L}$ whereas the interquartile arrange is from 224 - $448 \mathrm{mg} / \mathrm{L}$. Observed nitrates are less represented in "Moderate" (n=4 ranged from 101 - 460 $\mathrm{mg} / \mathrm{L})$ and "Very high" ( $\mathrm{n}=1 ; 210 \mathrm{mg} / \mathrm{L})$ vulnerability category. For DRASTIC_N, only the "high" vulnerability class is present. Nevertheless, the distribution of nitrate concentrations differs between minimum $(179-209 \mathrm{mg} / \mathrm{L})$ and maximum $(210-240 \mathrm{mg} / \mathrm{L})$ "high" vulnerability index values. Among the 43 samples, only four $(101,105$, 
vulnerability index comprised between $210-240$ where nitrates concentration are ranged from $70-599 \mathrm{mg} / \mathrm{L}$ $(\mathrm{n}=39$, median $=325 \mathrm{mg} / \mathrm{L})$. SINTACS presents a similar variability of nitrate concentrations than DRASTIC. The "High" vulnerability category involves $90 \%(\mathrm{n}=35)$ of the samples ranged from $69-599 \mathrm{mg} / \mathrm{L}$ with the 1 st quartile from 69 - $213 \mathrm{mg} / \mathrm{L}$. and the interquartile ranged from 213 - $452 \mathrm{mg} / \mathrm{L}$. The "Moderate" and "Very high" categories are less common with $\mathrm{n}=1 ; 315 \mathrm{mg} / \mathrm{L}$ and $\mathrm{n}=3$ ranged from $209-401 \mathrm{mg} / \mathrm{L}$ respectively. For SI, The "high" vulnerability category concerns $35 \%$ of the samples $(n=14)$ with concentrations between $101-567 \mathrm{mg} / \mathrm{L}$. The $1 \mathrm{st}$ quartile are ranged from $101-179 \mathrm{mg} / \mathrm{L}$ and the interquartile from $179-401 \mathrm{mg} / \mathrm{L}$. The Very high vulnerability is found in $65 \%$ of the samples $(\mathrm{n}=26)$ with concentrations between $69-599 \mathrm{mg} / \mathrm{L}$. The 1 st quartile are between $69-222 \mathrm{mg} / \mathrm{L}$ and the interquartile range between $222-449 \mathrm{mg} / \mathrm{L}$.

For TLF concentrations, DRASTIC map reveals that "moderate" vulnerability coincide with $12 \%$ of the TLF values ranged from 9 - $65 \mathrm{ppb}(\mathrm{n}=9$; median $=27 \mathrm{ppb})$. The "high" vulnerability class is represented by $88 \%$ of TLF from 5 - $210 \mathrm{ppb}$ ( $\mathrm{n}=64$, median=41 ppb). For DRASTIC_N, among the 73 samples, only 15\% ranged from $10-$ $70 \mathrm{ppb}$ are correlated with $179-209$ vulnerability index $(\mathrm{n}=11$, median $=28 \mathrm{ppb})$ whereas $85 \%$ of samples coincide with "high" vulnerability index comprised between 210 -240 where TLF concentrations are ranged from 5-210 $\mathrm{ppb}(\mathrm{n}=59$, median $=45 \mathrm{ppb})$. For SINTACS, only 3 TLF samples $(10,21$ and $51 \mathrm{ppb})$ coincide with "moderate" vulnerability class. The "high vulnerability is represented by $89 \%$ of the TLF values ranged from $5-210 \mathrm{ppb}$ ( $\mathrm{n}=65$; median $=40 \mathrm{ppb}$ ). Only five samples ranged from $32-54 \mathrm{ppb}$ coincide with "very high" vulnerability class. For SI, the "high" vulnerability class is correlated with $40 \%$ of TLF values ranged from 5 - $74 \mathrm{ppb}(\mathrm{n}=29$; median $=28 \mathrm{ppb}$ ). The "very high" vulnerability is more represented with $60 \%$ of the samples ranged from $8-210$ $\mathrm{ppb}(\mathrm{n}=44 ;$ median $=43 \mathrm{ppb})$.

In order to validate the vulnerability maps, a spatial correlation was made with observed nitrate concentrations. The nitrate concentrations map were obtained using average discrete values estimated to vary from 25 to $710 \mathrm{mg} / \mathrm{L}$. Those values were spatialized by IDW interpolation (Errors within -13 and $10 \mathrm{mg} / \mathrm{L}$ and RMSE $=5 \mathrm{mg} / \mathrm{L}$ ) and classified by their degree of contamination based on Stigter et al., 2006 (Fig. 7). The nitrate map thus obtained shows that the WHO guideline value (WHO, 2004) for drinking-water quality $(50 \mathrm{mg} / \mathrm{L}$ ) is largely exceeded throughout the study area. Highest nitrate concentrations $(>300 \mathrm{mg} / \mathrm{L})$ are observed throughout much of the study area.

\section{Discussion:}

Comparison of observed nitrate concentrations with four vulnerability maps reveals substantial differences. To facilitate validation of these assessment methods, a new set of maps was created by subtracting the assessed vulnerability class from observed nitrate contamination class as per Stigter et al., 2006. This process argues that when the difference between the classes is in the order of minus one, zero or one (meaning that the vulnerability class is one class higher, equal or lower than the nitrate contamination class), the vulnerability assessment is considered correct. If a difference in the order of two or three classes is obtained, the vulnerability assessment is considered overestimated or underestimated respectively. Finally, when the difference is higher or lower by four or five, the vulnerability assessment is extremely overestimated or extremely underestimated, respectively. The analysis of the maps obtained, coupled with the coincidence rate determination (Fig. 8) shows a better vulnerability/contamination correspondence given by the SI model (56\%). For the DRASTIC, SINTACS and DRASTIC_N methods, the correspondence rate is much lower (34, 38 and 43\% respectively). Mapped correlations 
of aquifer vulnerability to observed nitrate concentrations in Figure 9 also show the degree to which the four vulnerability assessments correctly estimate and either underestimate or overestimate the contamination risk.

Generally, the assessments by DRASTIC and SINTACS provide similar assessments of aquifer vulnerability. Both methods use the same parameters notwithstanding the higher weightings employed by SINTACS. Both underestimate vulnerability by a similar magnitude (coincidence rate). This underestimation occurs when the "moderate to high" vulnerability and "high" vulnerability classes coincide with "extremely high" levels of nitrate contamination. It may be due to the fact that these methods only assess intrinsic vulnerability without taking into account pollution risk derived from the vulnerability of the aquifer and pollutant load (Foster et al., 1987). Nevertheless, a good correspondence is established between vulnerability and contamination classes with a coincidence rate of $25 \%$ for the DRASTIC method and $28 \%$ for SINTACS. The inclusion of the new redox state parameter ( $\mathrm{N}$ ) in DRASTIC_N improves the vulnerability assessment despite the low sensitivity of some parameters such as the impact of the unsaturated zone and the hydraulic conductivity. Notwithstanding this improvement, coincidence rates remain significantly lower than the SI method (see below), despite the application of the maximum rate (10) for redox state condition.

In the SI method, explicit consideration of land cover with high values attributed to the urbanized zone (LU=75) and both soil and impact of the vadose zone parameters remove are the reasons for the good vulnerability estimation. In very small proportions (1\%), an overestimation of vulnerability is established for the SI and SINTACS methods. In the discontinuous built-up areas located to the east of the watershed, the risk of pollution is low but the parameters of vulnerability are high. The assignment of high rating to land use (LU=70) for SI as well as high weight to intrinsic recharge parameters and soil type for SINTACS lead to this overestimation. It is, however, preferable to an underestimation, in the sense that it involves the safe side of uncertainty. In other words, if vulnerability assessment were to be used by planners or decision-makers, negative consequences of uncertainty associated to underestimation would be avoided (Stigter et al., 2006).

Beyond these findings, the applicability of the DRASTIC and SINTACS methods to the study area is questionable. These methods take into account certain intrinsic parameters that in most cases are constrained in the study area. This is the case for I "Impact of the vadose zone" and S "soils" parameters. Indeed, in the urbanized zone with relatively shallow groundwater depth (less than 2 metres), a vast network of on-site sanitation facilities, primarily septic tanks exist above the Thiaroye aquifer (Cisse Faye et al., 2019). Recent work has shown densities of on-site sanitation vary between 1 and 70 septic tanks and pit latrines per hectare, with an average density of 20 per hectare (Diaw et al., 2020). This autonomous management of domestic wastewater suggests the use of soil as a filter bed which, because of its attenuation capacity, contributes to the reduction of pollution risks. This zone is characterized by the presence of septic tanks that are mostly leaking, latrines and sumps often built at depth (1 to 2 metres). The wastewater is either injected directly into the groundwater or percolates through a very thin unsaturated zone to reach the capillary fringe. This faecal loading is expected to play an important role in groundwater pollution as long as the ability of the unsaturated zone to attenuate contamination is limited. This is well observed in both DRASTIC and SINTACS methods integrating these parameters where, in the urbanized zone, vulnerability is underestimated. 


\section{Conclusions:}

Groundwater vulnerability to nitrate contamination in the Dakar urban aquifer was assessed at the catchment scale $\left(\sim 60 \mathrm{~km}^{2}\right)$ using DRASTIC, DRASTIC_N, SINTACS and SI overlay and index methods. Vulnerability indices obtained from these models identify 3 classes of vulnerability: moderate, high, and very high. Prevalence of the "very high" degree of vulnerability is greater in the SI method (36\%) relative to DRASTIC and SINTACS (5 and 9\% respectively). Intrinsic vulnerability models (DRASTIC and SINTACS) present similarities in their assessment of vulnerability as they employ a common set of parameters but consider neither the nature of the pollutants nor factors managing the specific vulnerability such as land use. Single-parameter sensitivity tests show that groundwater depth, soil, and topography have the greatest influence over the vulnerability rating. The shallowness of the water table and low relief of Dakar are considered to have the greatest influence on the vulnerability of groundwater to contamination. An improved correspondence is observed between assessed contamination by nitrate using the SI method (coincidence rate of 56\%) compared to DRASTIC, SINTACS and DRASTIC_N with lower coincidence rates of 34, 38 and 43\%, respectively. In the Thiaroye area of Dakar, representation of groundwater vulnerability using the SI method is improved by the explicit inclusion of land use. Our evidence from Dakar suggests that in urban areas of tropical Africa with shallow water tables, the SI method may prove to provide a more robust representation of groundwater vulnerability. Such assessments may prove invaluable for planning where groundwater quality monitoring data are absent.

\section{Acknowledgements}

This document is an output from the AfriWatSan project funded by The Royal Society Africa Capacity Building Initiative and the UK Department for International Development (DFID) (Grant Ref. AQ140023). The views expressed and information contained in it are not necessarily those of or endorsed by the Royal Society or DFID, which can accept no responsibility for such views or information or for any reliance placed on them.

\section{Conflicts of interest/Competing interests}

The authors declare that they have no competing financial interests or personal relationships that could have appeared to influence the work reported in this paper.

\section{Availability of data and material}

The data that support the findings of this study are available from the corresponding author, [A. P], upon reasonable request.

\section{Authors' contributions}

Abdoulaye Pouye: Writing (original draft, review \& editing), Data curation, Methodology, Software. Seynabou Cissé Faye: Supervision, review \& editing, Mathias Diedhiou: review \& editing, Cheikh Becaye Gaye: Supervision, Funding acquisition. Richard G. Taylor: Writing - review \& editing, funding acquisition. 
Agyemang, A., Beauty A. (2017). Vulnerability Assessment of Groundwater to $\mathrm{NO}_{3}$ Contamination Using GIS, DRASTIC Model and Geostatistical Analysis. Electronic Theses and Dissertations. Paper 3264. https://dc.etsu.edu/etd/3264.

Aké, G.E., Kouadio, H.B., Dongo, K., Dibi, B., Kouamé, F.K., Biemi, J. (2010). Application des méthodes DRASTIC et SI pour l'étude de la vulnérabilité à la pollution par les nitrates $\left(\mathrm{NO}_{3}{ }^{-}\right)$de la nappe de Bonoua (Sud-Est de la Côte d'Ivoire). Int. J. Biol. Chem. Sci. 17.

Al-Abadi, A.M., Al-Shamma'a, A.M., Aljabbari, M.H., (2014). GIS-based DRASTIC model for assessing intrinsic groundwater vulnerability in northeastern Missan governorate, southern Iraq. Appl. Water Sci. 13. https://doi.org/10.1007/s13201-014-0221-7.

Alam, F, Umar, R., Ahmad, S., Dar, A.F. (2012). A new model (DRASTICLU) for evaluating groundwater vulnerability in parts of Central Ganga plain, India. Arabian Journal of Geosciences 7:927-937. DOI 10.1007/s12517-012-0796-y.

Aller, L., Bennett, T., Lehr, J.H., Petty, R.J., Hackett, G., (1987). DRASTIC: A Standardized System for Evaluating Ground Water Pollution Potential Using Hydrogeologic Settings. U.S. Environmental Protection Agency, Ada (OK), USA. No. EPA/2-87/035.

Antea-senagrosol, (2003). Projet Eau à Long Terme : Etude d'impact de l'arrêt des forages de Thiaroye, Modélisation des scénarios d'arrêt, Evaluation des impacts hydrogéologiques, Phases BTC, Rapp. A33129/A, 73p.

Armanuos, A.M., Allam, A., Negm, A.M. (2019). Assessment of groundwater vulnerability to pollution in western nile delta aquifer, Egypt. Arabian Journal of Geosciences. DOI 10.1007/s12517-019-4883-1

Babiker, I. S., Mohamed, M. A., Hiyama, T., Kato, K. (2005). A GIS-based DRASTIC model for assessing aquifer vulnerability in Kakamigahara Heights, Gifu Prefecture, central Japan. Science of the Total Environment, 345(1), 127-140.

Baker, A. (2002). Fluorescence properties of some farm waste, implications for water quality monitoring. Water Res. 39 (18). 4405-4412.

Batchi, M., Karkouri, J.A., Fenjiro, I., Maaqili, M.E. (2017). Étude comparative de deux modèles (DRASTIC et SI) pour l'évaluation de la sensibilité de la nappe phréatique de Mnasra (Maroc nord-occidental) à la pollution d'origine agricole. Physio-Géo, Volume 11 -1, 43-64..

Batista, S. (2004). Exposição da água subterrânea a pesticidas e nitratos em ecossistemas agrícolas do Ribatejo e Oeste e da Beira Litoral. Tese de doutoramento em engenharia agronómica, Instituto superior de agronomia, Lisboa, p.19

Cissé Faye, S., (2001). Nappe libre des sables quaternaires Thiaroye/Beer Thialane: Etude de la contamination par les nitrates sur la base d'un Système d'informations géographiques ( $\mathrm{PC}$ Arc/info). Thèse de 3e cycle. UCAD, Dakar.

Civita, M., De Maio, M. (1997). SINTACS. Un sistema parametrico per la valutazione e la cartografia della vulnerabilità degli acquiferi all'inquinamento. Metodologia \& Automatizzazione. Pitagora Editrice, Bologna, Italia.

Comte, J.-C., Banton O., Sambou S., Travi I., Ouédraogo S. (2012). L'aquifère des sables de la presqu'île de Dakar (Sénégal): état de la ressource et impacts anthropiques. 18èmes journées techniques du Comité Français d'Hydrogéologie de l'Association Internationale des Hydrogéologues. « Ressources et gestion des aquifères littoraux, cassis, France. hal-01315455.

Cuthbert, M. (2010). An improved time series approach for estimating groundwater recharge from groundwater level fluctuations. Water Resour Res 46:W09515.

Cuthbert, M.O., Taylor, R.G., Favreau, G., Todd, M.C., Shamsudduha, M., Villholth, K.G., MacDonald, A.M., Scanlon, B.R., et al. (2019). Observed controls on resilience of groundwater to climate variability in sub-Saharan Africa. Nature 572, 230-234. https://doi.org/10.1038/s41586-019-1441-7.

Diedhiou, M., Cisse Faye S., Diouf, O. C., S. Faye, A. Faye, V. Re, S. Wohnlich, F. Wisotzky, U. Schulte, Maloszewski P. (2012). Tracing groundwater nitrate sources in the Dakar suburban area : an isotopic multi - tracer approach. . Hydrol Process vol. 26:760-770. https://doi.org/10.1002/hyp.8172.

.Diouf, O. C., Cisse Faye, S., Diedhiou, M., Kaba, M., Faye, S., Gaye, C. B., Faye, A., Englert, A., Wohnlich, S. (2012). Combined uses of water-table fluctuation (WTF), chloride mass balance (CMB) and environmental isotopes methods to investigate groundwater recharge in the Thiaroye sandy aquifer (Dakar, Senegal). African Journal of Environment Sciences and Technologies Vol. 6(11). 425-437. DOI: 10.5897/AJEST12.100.

European Community (1993). Corine land cover. Guide technique. Office des Publications Officielles des Communautés Européennes, Série environnement, sécurité nucléaire et protection civile, 144 p. 
Frances, A, Paralta, E, Fernandes, J, Ribeiro, L. (2002). Development and application in the Alentejo region of a method to assess the vulnerability of groundwater to diffuse agricultural pollution: the susceptibility index, FGR'01, Third Int. Conf. on Future Groundwater Resources at Risk CVRM publ., Lisbon, 35-44.

Ferral, A., Sarmiento, T. M., Alaniz, E., Ferral, A. (2014). Assessment, monitoring and protection of groundwater pollution in urban areas Cordoba city - Argentina. Environmental Science.9. DOI:10.19044/esj.2014.v10n7p\%p.

Foster, S., Bousquet, A., Furey, S. (2018). Urban groundwater use in Tropical Africa - a key factor in enhancing water security? Water Policy. 20. 982-994. https://doi.org/10.2166/wp.2018.056.

Ghosh, A, Tiwari, A.K., Das, S. (2015). A GIS based DRASTIC model for assessing groundwater vulnerability of Katri Watershed, Dhanbad, India. Model Earth Syst. Environ 1(3):11. DOI:10.1007/s40808-015-0009-2.

Grönwall, J.T., Mulenga, M., McGranahan, G. (2010). Groundwater, self-supply and poor urban dwellers: A review with case studies of Bangalore and Lusaka. IIED. 103. ISBN: 978-1-84369-770-1

Hamza, M.H., Added, A., Francès, A., Rodriguez, R., Ajmi, M., Abdeljaoued, S. (2008). Évaluation de la vulnérabilité à la pollution potentielle de la nappe côtière alluvionnaire de meltine-ras jebel-raf raf (nordest tunisien) selon les méthodes paramétriques DRASTIC, SINTACS et SI. Rev. Sci. Eau J. Water Sci. 13. https://doi.org/10.7202/017932ar

Hamza, M.H., Maâlej, A., Ajmi, M., Added, A. (2010). Validity of the vulnerability methods DRASTIC and SI applied by GIS technique to the study of diffuse agricultural pollution in two phreatic aquifers of a semiarid region (Northeast of Tunisia). AQUAmundi 1009: 057 - 064. DOI 10.4409/Am-006-10-0009

Hansen, B., Sonnenborg, T.O., Møller, I., Bernth, J.D., Høyer, A.-S., Rasmussen, P., Sandersen, P.B.E., Jørgensen, F., (2016). Nitrate vulnerability assessment of aquifers. Environ Earth Sci 75, 999. https://doi.org/10.1007/s12665-016-5767-2.

Howard, G., Pedley, S., Barrett, M.H., Nalubega, M., Johal, K., (2003). Risk factors contributing to microbiological contamination of shallow groundwater in Kampala, Uganda. Water Research 37(14): 3421-3429.

Jourda, J. P., Kouame, K. J., Adja, M.G., Deh, S. K., Anani, A. T.1, Effini, A. T., Biemi, J.( 200)7. Evaluation du degré de protection des eaux souterraines vulnérabilité à la pollution de la nappe de Bonoua (Sud-Est de la Côte d'Ivoire) par la méthode DRASTIC. Conférence Francophone ESRI, 10-11 Octobre-Versailles, 8pp.

Kumar, P., Thakur, P.K., Bansod, B.K.S., Debnath, S.K. (2016). Assessment of the effectiveness of DRASTIC in predicting the vulnerability of groundwater to contamination: a case study from Fatehgarh, Sahib district in Punjab, India. Environ. Earth Sci. 75 (10), 1 -13. http://dx.doi.org/10.1007/s12665-016-5712-4.

Kumar, P., Baban, K.S.B., Sanjit, K.D., Praveen, K.T., Ghanshyam, C. (2017). Index-based groundwater vulnerability mapping models using hydrogeological settings: a critical evaluation. Environ Impact Assess Rev 51:38-49. https://doi.org/10.1016/j.eiar.2015.02.001.

Klug, J.L. (2009). Modeling the Risk of Groundwater Contamination Using DRASTIC and Geographic Information Systems in Houston County, Minnesota. Papers in Resource Analysis Vol. 11. 12 pp. Saint Mary's University of Minnesota University Central Services Press. Winona, MN.

Lobo F., Oliveira M. (2004). Groundwater vulnerability assessment in Portugal. Geofísica Internacional, Vol. 43, Num. 4, pp. 541-550.

Madioune, D. H., Cissé Faye, S., Faye, S. (2011). Etude de la vulnérabilité intrinsèque à la pollution de la nappe libre des sables quaternaires de thiaroye par la methode DRASTIC. J. Sci. Technol. 2011 Vol $9 \mathrm{~N}^{\circ} 2$ Pp11111.

Maignien, R. 1959. Les sols de la presqu'île du Cap-Vert. Rapport technique Office de la Recherche Scientifique et Technique Outre-Mer (ORSTOM) Dakar-Hann. 163 p.

Marjuanto, A.A., Putranto, T.T., Sugianto, D. N. 2019. Mapping of Groundwater Vulnerability Index in the Alluvial Plain of Semarang City Using the Susceptibility Index Method. E3S Web of Conferences. 6.

Martin, A. (1970). Les nappes de la presqu'île du Cap-Vert. Leur utilisation pour l'alimentation en eau de Dakar. Publ. BRGM, 50p.

Ministère du Renouveau urbain, de l'habitat et du cadre de vie (MRU). Agence Japonaise de Coopération Internationale JICA. (2016). Plan Directeur d'Urbanisme de Dakar et ses Environs Horizon 2035. Report. 321 .

Muhammad, K.M., Zhonghua, T., Dawood, A.S., Earl, B. (2014). Evaluation of local groundwater vulnerability based on DRASTIC index method in Lahore, Pakistan. Geofísica Internacional. Volume 54, Pages 67-81.

National Research Council (NRC). (1993). Groundwater vulnerability assessment, contamination potential under conditions of uncertainty. National Academy Press, Washington DC.

Neh, A.V., Ako, A.A., Akoachere, R. A., II, Hosono, T. (2014). DRASTIC-GIS model for assessing vulnerability to pollution of the phreatic aquiferous formations in Douala-Cameroon. Journal of African earth sciences. 200411.001.

Oke, S.A., Fourie, F. (2017). Guidelines to groundwater vulnerability mapping for Sub-Saharan Africa. Groundwater for Sustainable Development, Volume 5 - Pages 168-177. DOI: 10.1016/j.gsd.2017.06.007. 
Oke, S.A., (2020). Regional Aquifer Vulnerability and Pollution Sensitivity Analysis of Drastic Application to Dahomey Basin of Nigeria. Int. J. Environ. Res. Public Health, 17, 2609. https://doi.org/10.3390/ijerph17072609.

Ojuri, O.O., Olufunmilola, T. Bankole, O.T. (2013). Groundwater Vulnerability Assessment and Validation for a Fast Growing City in Africa: A Case Study of Lagos, Nigeria. Journal of Environmental Protection 04(05):454-465.

Panagopoulos, G.P., Antonakos, A.K., Lambrakis, N.J. (2006). Optimization of the DRASTIC method for groundwater vulnerability assessment via the use of simple statistical methods and GIS. Hydrogeology Journal 14(6):894-911. DOI: 10.1007/s10040-005-0008-x.

Pradhan, B., Neshat, A., Pirasteh, S., Shafri H.Z.M. (2013). Estimating groundwater vulnerability to pollution using a modified DRASTIC model in the Kerman agricultural area Iran. Environmental Earth Sciences 71(7). DOI: 10.1007/s12665-013-2690-7.

Rahman, A. (2008). A GIS based DRASTIC model for assessing groundwater vulnerability in shallow aquifer in Aligarh, India. Applied Geography 28(1):32-53. DOI: 10.1016/j.apgeog.2007.07.008

Ribeiro, L. (2000). IS: Um novo índice de susceptibilidade de aquíferos à contaminação agrícola Internal report. ERSHA/CVRM, Instituto Superior Ténico Lisbon, Portugal, p. 12

Ribeiro, L., Pindo, J.C., Luis Dominguez-Granda. (2016). Assessment of groundwater vulnerability in the Daule aquifer, Ecuador, using the susceptibility index method. Science of The Total Environment 574. DOI: 10.1016/j.scitotenv.2016.09.004.

Roger, J., Banton, O., Barusseau, J.P., Castaigne, P., Comte, J. C., Duvail, C., Nehlig P., Noël, B.J., Serrano, O., Travy, I. (2009). Notice explicative de la cartographie multicouche à 1/50 000 et 1/20 000 de la zone d'activité du Cap-Vert. Ministère des Mines, de l'Industrie et des PME, Direction des Mines et de la Géologie, Dakar, 245 pages.

Saidi, S., Bouri, S., Ben Dhia, H. (2009). Groundwater vulnerability and risk mapping of the Hajeb-jelma aquifer (Central Tunisia) using a GIS-based DRASTIC model. Environmental Earth Sciences 59 (7), 1579-1588.

Shrestha, S., Kafle, R., Pandey, V.P. (2017). Evaluation of index-overlay methods for groundwater vulnerability and risk assessment in Kathmandu Valley, Nepal. Science of The Total Environment 575. DOI: 10.1016/j.scitotenv.2016.09.141.

Si, A.A., Yahiaoui, N. (2017). Etude de la vulnérabilité à la pollution de la région de Boulimat par la méthode SINTACS (Master). Université Abderrahmane Mira-Bejaia, Algérie.

Singh, A., Srivastav S. K., Kumar S., Chakrapani G. J. (2015). A modified-DRASTIC model (DRASTICA) for assessment of groundwater vulnerability to pollution in an urbanized environment in Lucknow, India. Environmental Earth Sciences 74(7). DOI: 10.1007/s12665-015-4558-5.

Sorensen, J.P.R., Diaw, M.T., Pouye, A., Roffo, R., Diongue, D.M.L., Cissé Faye, S., Gaye, C. B., Fox, B. G., Goodall, T., Lapworth, D.J., MacDonald, A.M., Reade, D.S., Ciric, L. \& Taylor, R.G. (2020): Insitufluorescence spectroscopy indicates total bacterialabundance and dissolved organic carbon.Science of the TotalEnvironmentdoi:10.1016/j.scitotenv.2020.139419.

Sow, N.R. (2009). Impact de la dynamique de l'occupation du sol sur les ressources en eau dans la region de Dakar : Approche par Télédétection et SIG. Memoire D.E.A 130 p. Dept of geology, Cheikh Anta University of Dakar, Senegal.

Stigter, T.Y., Ribeiro, L., Dill, • Carvalho A. M. M. (2006). Evaluation of an intrinsic and a specific vulnerability assessment method in comparison with groundwater salinisation and nitrate contamination levels in two agricultural regions in the south of Portugal. Hydrogeology Journal, 14, 79-99. http://dx.doi.org/10.1007/s10040-004-0396-3.

Tandia, A.A. (2000). Origine, évolution et migration des formes de l'Azote minéral dans les aquifères situés sous environnement péri-urbain non assaini: cas de la nappe des sables quaternaires de Dakar (SENEGAL) Thèse d'état. UCAD, Dakar.

Vallet, P. (1972). Approvisionnement en eau et assainissement de Dakar et ses environs, Etude des eaux souterraines, Tome II : Etude hydrogéologique de la nappe des sables quaternaires, Rapp. OMS, Projet Sénégal 3201, 139 p.

Voutchkova, D.D., Schullenher, J., Rasmussen P., Hansen, B. (2020). A high-resolution nitrate vulnerability assessment of sandy aquifers (DRASTIC-N). Journal of Envir. Management 277 (2021) 111330.

World Health Organisation (WHO). (2004). Guidelines for Drinking Water Quality: Recommendations. 3rd Edition, vol. 1, WHO, Geneva.

Yin, L., Zhang E., Wang, X., Wenninger, J., Dong J., • Li, G., Huang, J. (2011). A GIS-based DRASTIC model for assessing groundwater vulnerability in the Ordos Plateau, China. Environ Earth Sci 69:171185 DOI 10.1007/s12665-012-1945-z. 


\section{FIGURES:}

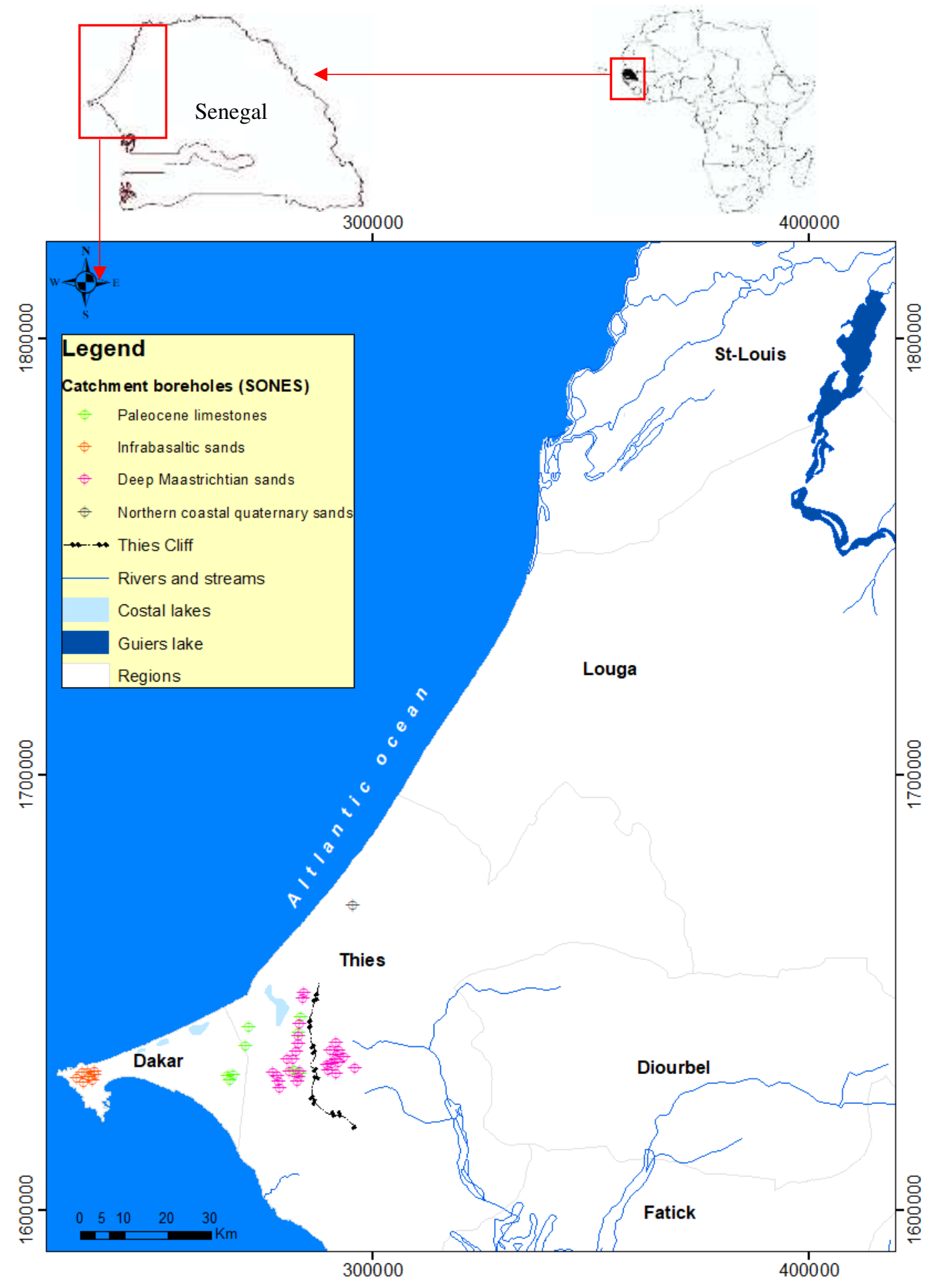

Figure 1: Map of the western Senegal showing drinking water supply sources of Dakar including Lac de Guiers and local groundwater catchment areas (Roger et al., 2009) and the eastern boundary of the Cape Verde peninsula (Thies cliff). 

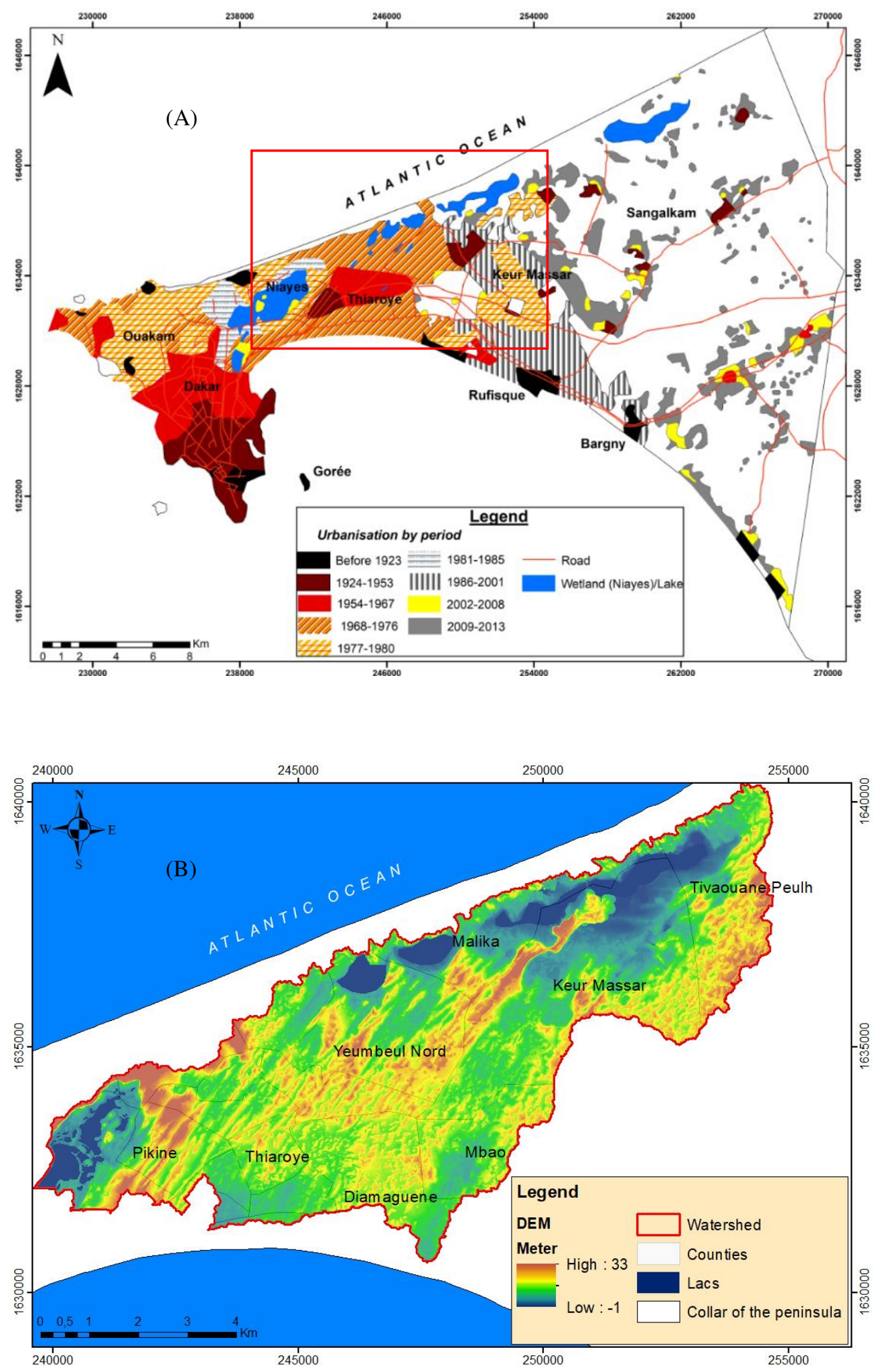

Figure 2: Map of the Cape Verde peninsula showing the context of the study area showing the historical evolution of urban development in Dakar (MRU. 2016) (A); topographical delineation of the study area, the Thiaroye catchment (B). 

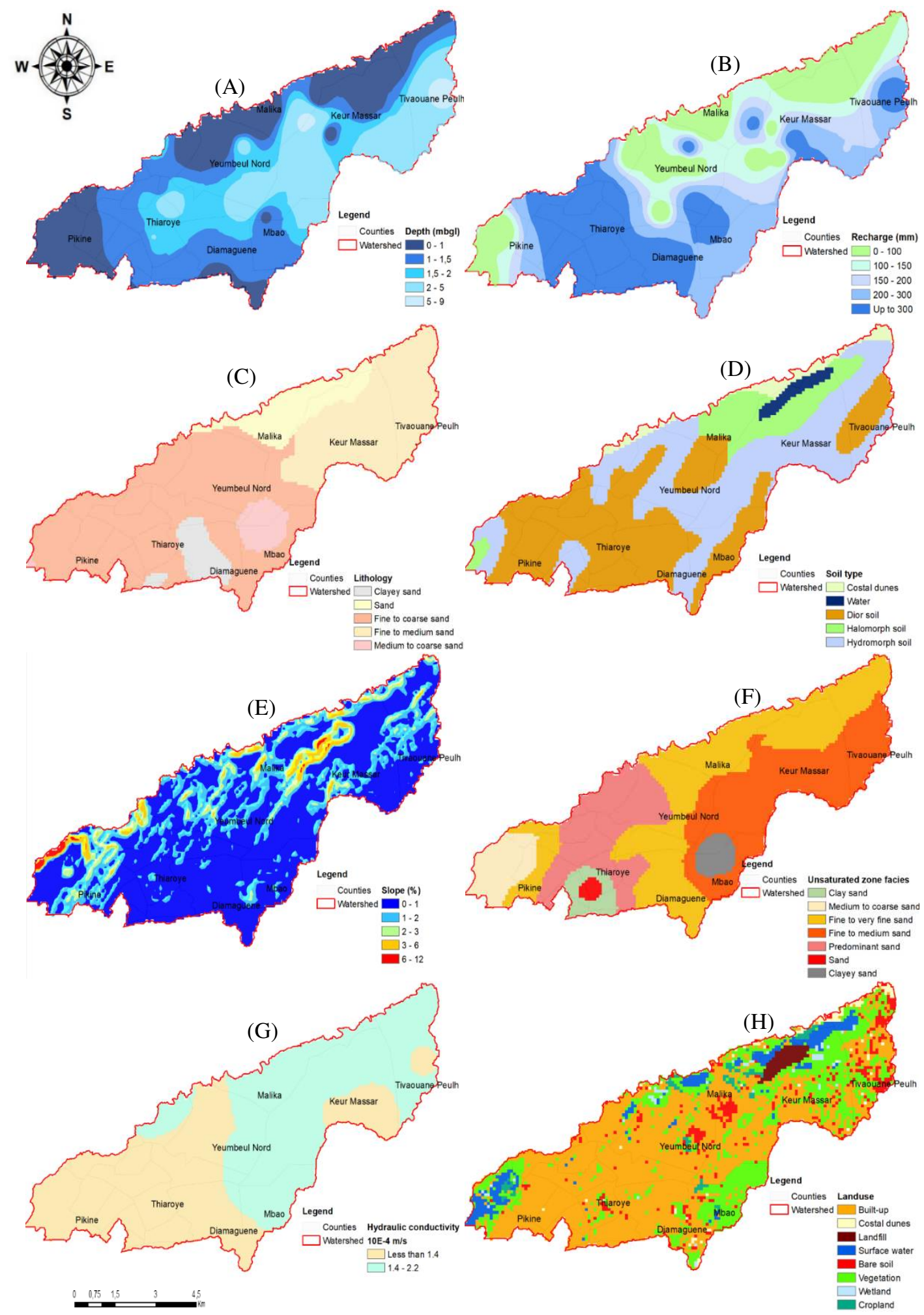

Figure 3: Input parameters used in groundwater vulnerability mapping: (A) Groundwater depth, (B) Net recharge, (C) Aquifer lithology, (D) Soil types, (E) Topography, (F) Impact of vadose zone, (G) Hydraulic conductivity and (H) Landuse. 

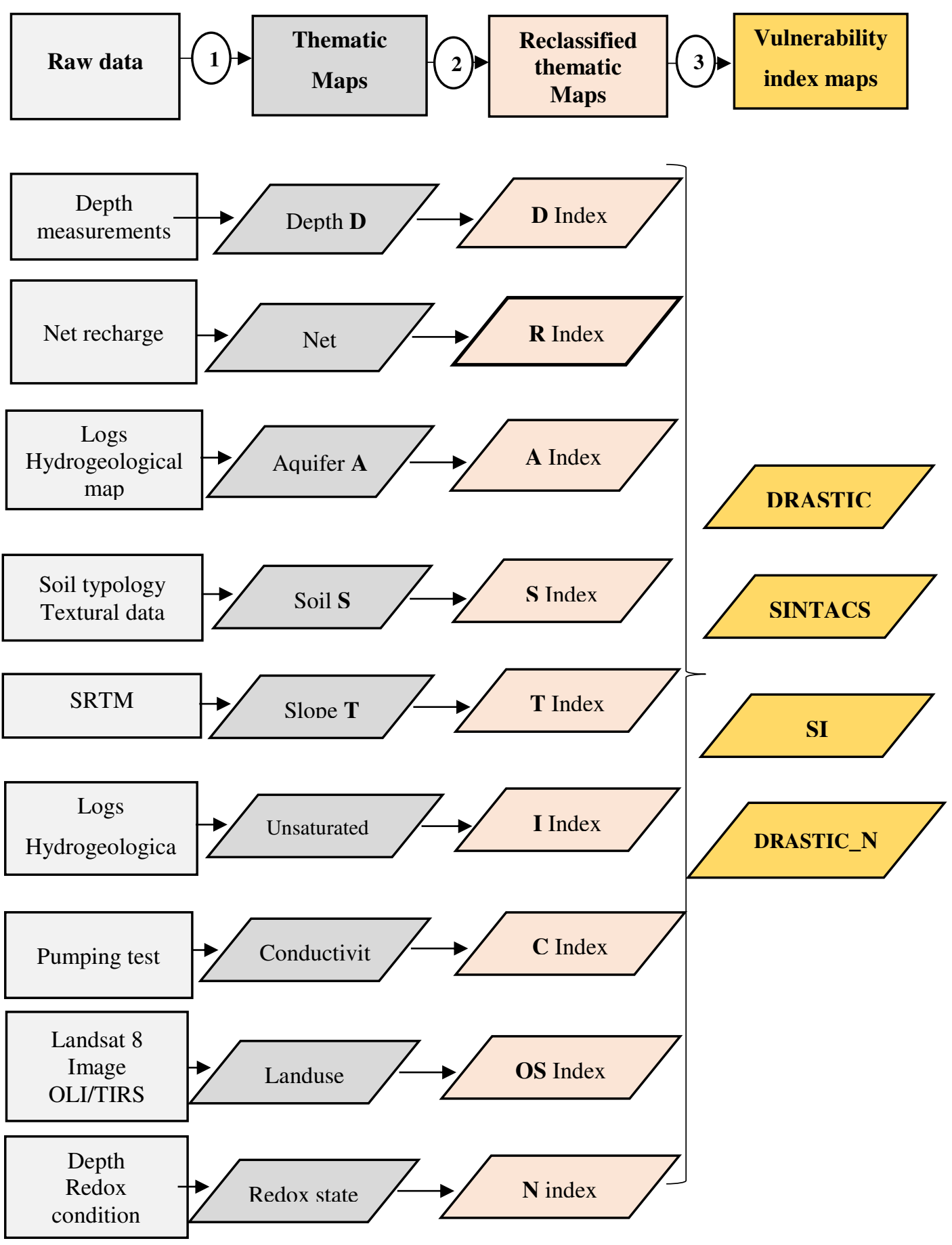

Figure 4: Organization chart of the analysis process

(1)= Digital interpolation, spatialization of point data and digitalization of vector data. The results give raster maps of meshes $100 \times 100$ meters.

(2)= Reclassification of the raster data according to the different quotations.

(3)= Superposition of re-classified maps and calculation of the various vulnerability indexes. 

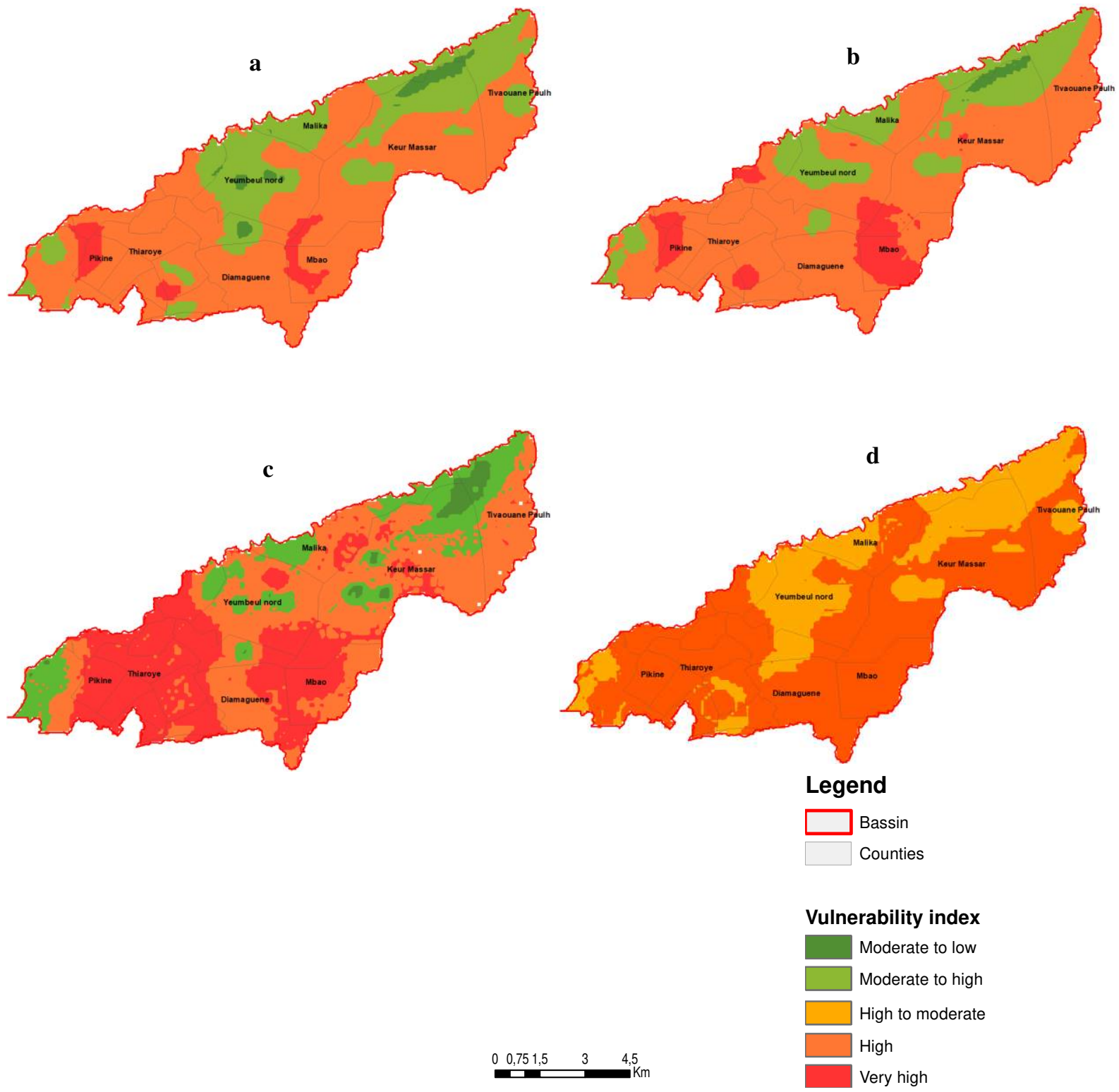

Figure 5: Vulnerability maps of the Thiaroye aquifer at catchment scale according to the (a) DRASTIC, (b) SINTACS, (c) SI and (d) DRASTIC_N methods 

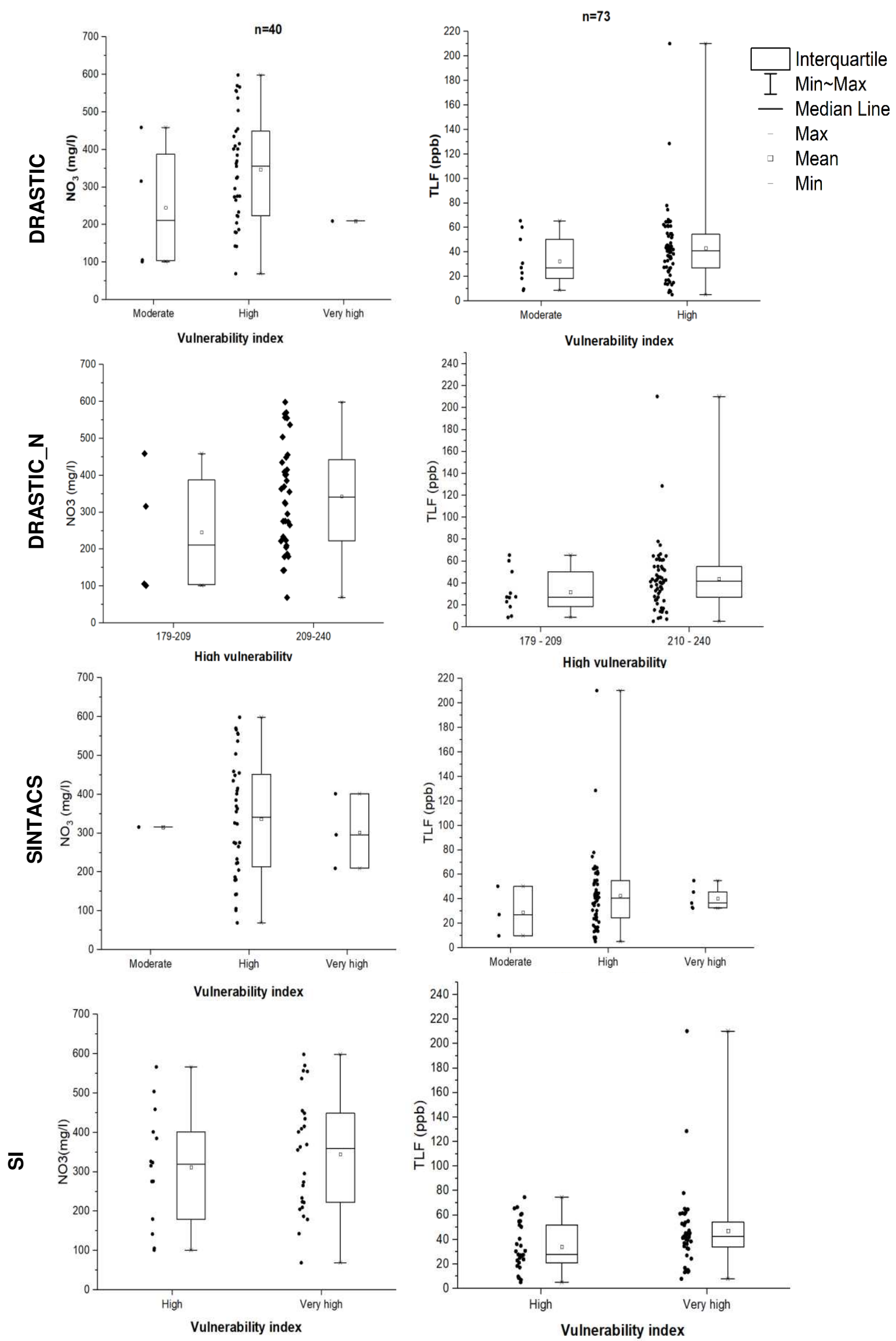

Figure 6: Box-plots of observed $\mathrm{NO}_{3}{ }^{-} / \mathrm{TLF}$ and vulnerability classes, representing the median, mean, $50^{\text {th }}$ and $75^{\text {th }}$ percentiles as vertical boxes and symbols as values vertical distribution. 


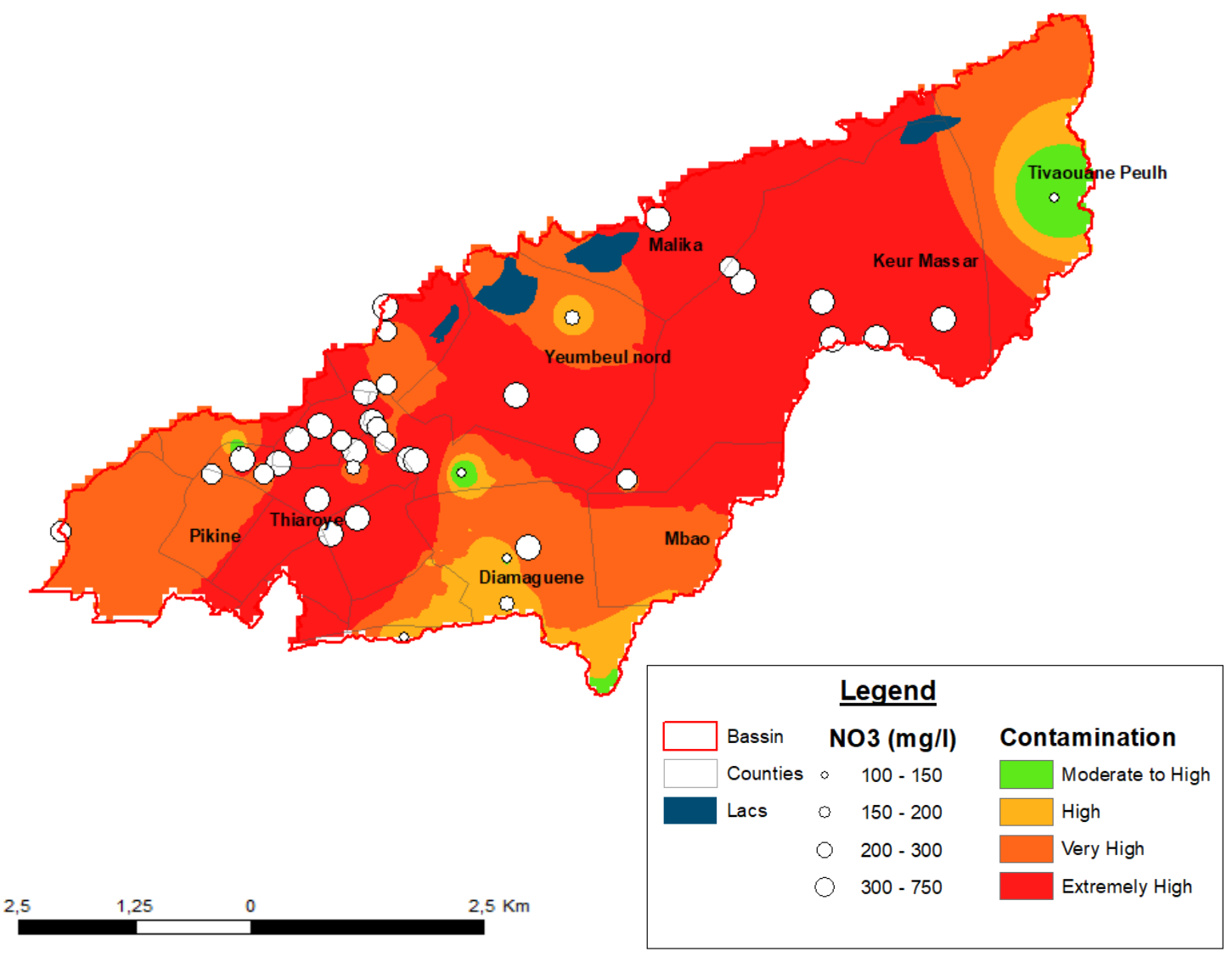

Figure 7: Distribution of Nitrate concentrations in the Thiaroye catchment scale 


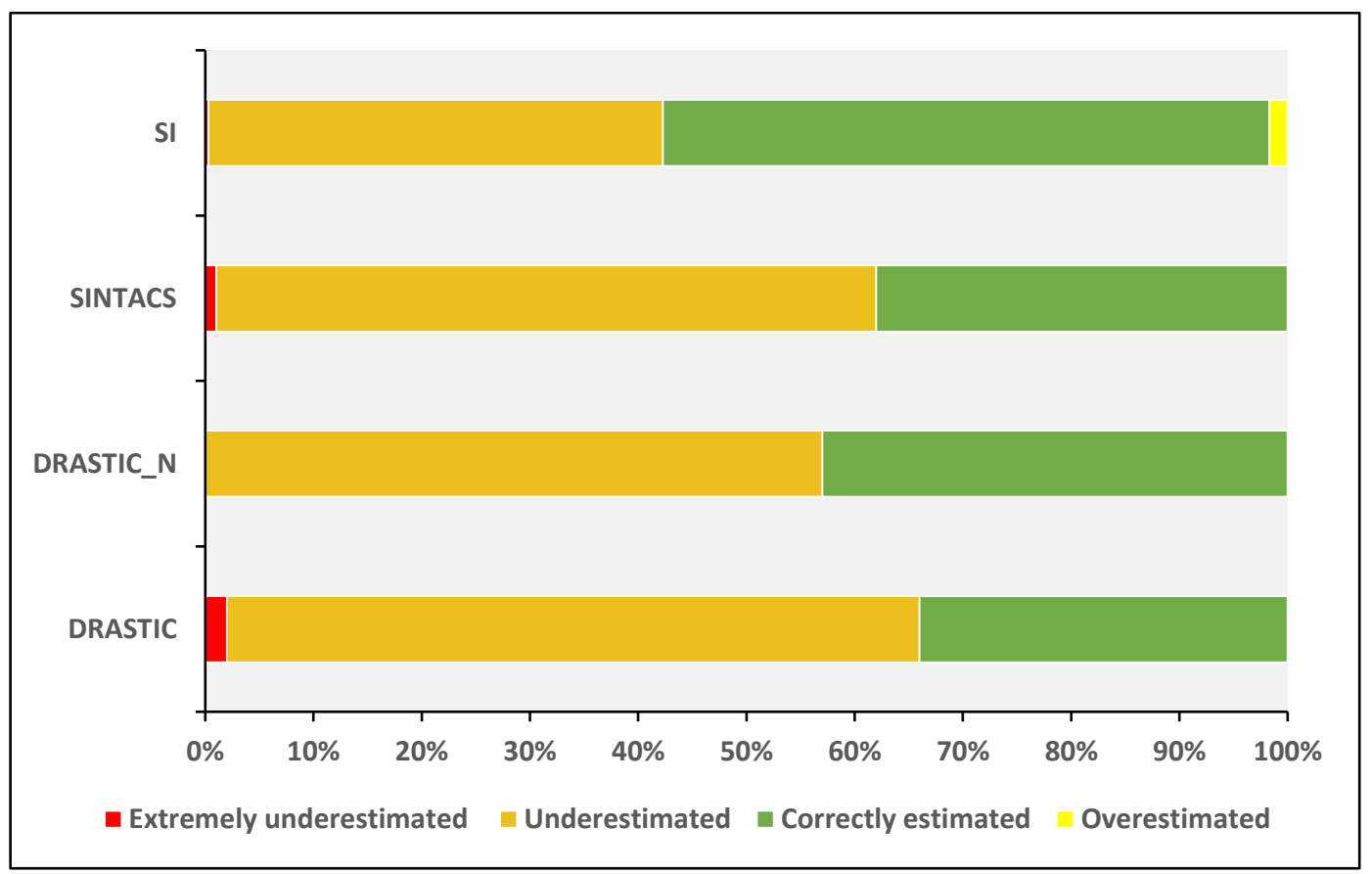

Figure 8: Stacked bars of correlation rate between vulnerability and nitrates contamination maps derived from SI, SINTACS, DRACTIC and DRASTIC_N methods 

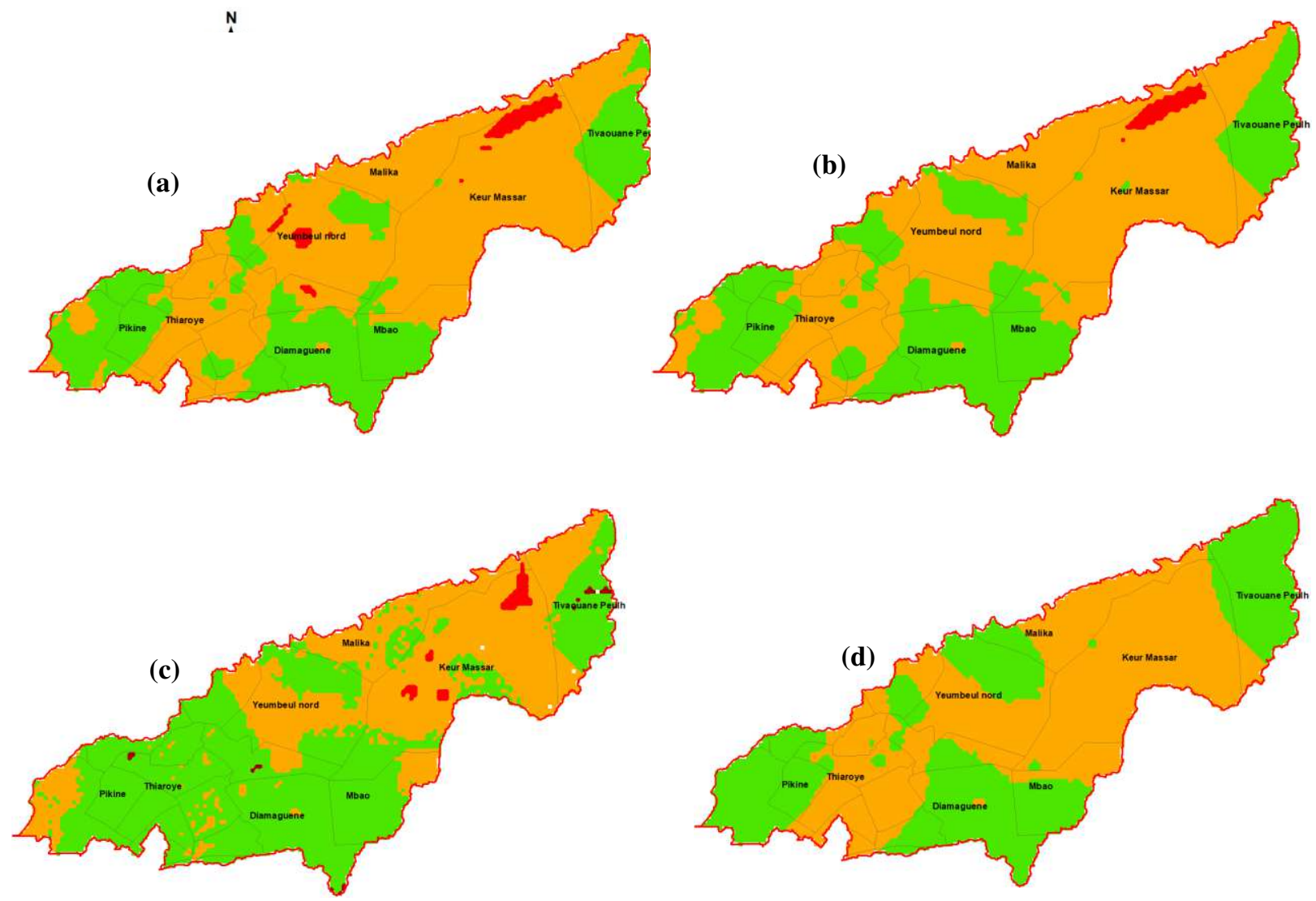

\section{Legend}

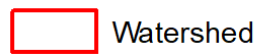

Counties

\section{Validation}

\begin{tabular}{|c|}
\hline Extremely underestimated \\
\hline Underestimated \\
\hline Correctly estimated \\
\hline Overestimated \\
\hline
\end{tabular}

Figure 9: Correlation map between observed nitrate concentrations and aquifer vulnerability defined by DRASTIC (a), SINTACS (b) SI (c) and DRASTIC_N (d) as per Stigter et al. (2006). 


\section{TABLES:}

Table 1:

Generic DRASTIC parameter weights (Aller et al., 1987)

\begin{tabular}{cc}
\hline Parameters & Weights \\
\hline (D) groundwater depth & 5 \\
(R) net recharge & 4 \\
(A) aquifer lithology & 3 \\
(S) soil type & 2 \\
(T) topography & 1 \\
(I) impact of the unsaturated zone & 5 \\
(C) hydraulic conductivity & 3 \\
\hline
\end{tabular}

Table 2:

Vulnerability assessment criteria (categories and ranges) in the DRASTIC method (Aller \& al., 1987).

\begin{tabular}{cc}
\hline Vulnerability degree & Vulnerability index \\
\hline Extremely low & $<80$ \\
Very low & $80-99$ \\
Low & $100-119$ \\
Moderate & $120-159$ \\
High & $160-179$ \\
Very high & $180-199$ \\
Extremely high & $>200$ \\
\hline
\end{tabular}

Table 3

Weights assigned to the different scenarios in the SINTACS method.

\begin{tabular}{cccccc}
\hline $\begin{array}{c}\text { Scenario } \\
\text { Parameters }\end{array}$ & $\begin{array}{c}\text { Normal } \\
\text { impact }\end{array}$ & Severe impact & $\begin{array}{c}\text { Significant } \\
\text { drainage }\end{array}$ & Karst & $\begin{array}{c}\text { Fractured } \\
\text { terrain }\end{array}$ \\
\hline S & 5 & 5 & 4 & 2 & 3 \\
I & 4 & 5 & 4 & 5 & 3 \\
N & 5 & 4 & 4 & 1 & 3 \\
T & 4 & 5 & 2 & 3 & 4 \\
A & 3 & 3 & 5 & 5 & 5 \\
C & 3 & 2 & 5 & 5 & 5 \\
S & 2 & 2 & 2 & 5 & 4 \\
\hline
\end{tabular}

Table 4:

Vulnerability assessment criteria (categories and ranges) using in SINTACS method (Civita et al., 1997).

\begin{tabular}{cc}
\hline Vulnerability degree & Vulnerability index \\
\hline Low & $<106$ \\
Moderate & $106-186$ \\
High & $186-210$ \\
Very high & $>210$ \\
\hline
\end{tabular}


Table 5:

Summary table of the rating in the SI method for the different land use types from CORINNE Land Cover.

\begin{tabular}{cc}
\hline $\begin{array}{c}\text { Land cover classes according to } \\
\text { CORINNE Land Cover }\end{array}$ & $\begin{array}{c}\text { Landuse ranges factor } \\
\text { LU (Landuse Factor) }\end{array}$ \\
\hline Industrial landfill, Municipal landfill, mines & 100 \\
Irrigated perimeters, rice fields & 90 \\
Quarry, shipyard & 80 \\
Artificial covered zones, green zones, continuous urban & 75 \\
Zones & 70 \\
Permanent cultures (vines, orchards, olive trees, etc.) & 70 \\
Discontinuous Urban zones & 50 \\
Pastures and agro-forest zones & 50 \\
Aquatic environment (swamps, saline, etc.) & 0 \\
Forest and semi-natural zones &
\end{tabular}

Table 6:

Susceptibility Index parameter weights according Ribeiro et al. (2000).

\begin{tabular}{lccccc}
\hline Parameters & D & R & A & T & OS \\
\hline Weights & 0.186 & 0.212 & 0.259 & 0.121 & 0.222 \\
\hline
\end{tabular}

Table 7:

Vulnerability assessment criteria (categories and ranges) using in SI method (Stigter \& al., 2006).

\begin{tabular}{cc}
\hline Vulnerability degree & Vulnerability index \\
\hline Low & $<50$ \\
Moderate & $50-70$ \\
High & $70-80$ \\
Very high & $80-100$ \\
\hline
\end{tabular}


Table 8:

Datasets employed in the evaluation of different vulnerability assessment methods.

\begin{tabular}{|c|c|c|c|c|c|}
\hline Parameters & Input data & DRASTIC & DRASTIC_N & SINTACS & SI \\
\hline $\begin{array}{l}\text { Groundwater } \\
\text { depth }\end{array}$ & $\begin{array}{l}\text { Dry season field data (April, } \\
2017 \text { ) }\end{array}$ & $\bigotimes$ & $\bigotimes$ & $\bigotimes$ & $\bigotimes$ \\
\hline Net recharge & $\begin{array}{l}\text { Bibliography (Antea- } \\
\text { Senagrosol, 2003, Comte \& al. } \\
\text { 2012) }\end{array}$ & $\bigotimes$ & $\bigotimes$ & $\bigotimes$ & $\bigotimes$ \\
\hline $\begin{array}{l}\text { Aquifer } \\
\text { lithology }\end{array}$ & $\begin{array}{l}\text { Bibliography (Cissé Faye, } \\
\text { 2001., Madioune \& al, 2011) }\end{array}$ & $\bigotimes$ & $\bigotimes$ & $\bigotimes$ & $\bigotimes$ \\
\hline Soil type & $\begin{array}{l}\text { Bibliography (Maignien, } \\
\text { 1959, FAO World Soil } \\
\text { Harmonized Database) }\end{array}$ & $\bigotimes$ & $\bigotimes$ & $\bigotimes$ & $\square$ \\
\hline Topography & SRTM (USGS) & $\bigotimes$ & $\bigotimes$ & $\bigotimes$ & $\square$ \\
\hline $\begin{array}{l}\text { Impact of the } \\
\text { unsaturated zone }\end{array}$ & $\begin{array}{l}\text { Bibliography (Madioune et al. } \\
\text { 2011) }\end{array}$ & $\bigotimes$ & $\bigotimes$ & $\bigotimes$ & $\square$ \\
\hline $\begin{array}{l}\text { Hydraulic } \\
\text { conductivity }\end{array}$ & $\begin{array}{l}\text { Bibliography } \\
\text { (Geohydraulique, 1972) }\end{array}$ & $\bigotimes$ & $\bigotimes$ & $\bigotimes$ & $\square$ \\
\hline Landuse & $\begin{array}{l}\text { Landsat } 8 \text { Image (USGS) } \\
\text { Avril } 2017\end{array}$ & $\square$ & 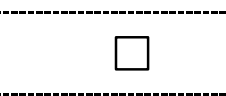 & $\Gamma$ & $\bigotimes$ \\
\hline $\begin{array}{l}\text { Redox } \\
\text { conditions }\end{array}$ & $\begin{array}{l}\text { Field data (groundwater depth } \\
\text { and chemistry) }\end{array}$ & $\square$ & $\bigotimes$ & $\square$ & $\square$ \\
\hline
\end{tabular}

Table 9:

Summary table of estimated recharge values for the Thiaroye aquifer quaternary sand and the methods used in previous studies.

\begin{tabular}{lccc}
\hline \multicolumn{1}{c}{ Approaches } & Method & References & $\begin{array}{c}\text { Value range } \\
(\mathbf{m m} / \mathbf{y})\end{array}$ \\
\hline \multirow{2}{*}{ Water balance } & Albrecht, 1951 & Cisse Faye, 2001 & $32-50$ \\
\hline Groundwater modelling & Turc & Cisse Faye, 2001 & 85 \\
\cline { 2 - 4 } CMB & 2D Flow density model & Comte et al., 2012 & $0-450$ \\
\hline \multirow{2}{*}{ Water table fluctuations } & Chloride mass balance & Diouf et al., 2012 & $9.9-73.7$ \\
\cline { 2 - 4 } & Healy et Cook., 2002 & Diouf et al., 2012 & $13-139$ \\
\cline { 2 - 4 } & Cuthbert et al., 2010 & Diongue, 2018 & 423 \\
\cline { 2 - 4 } & Cuthbert et al., 2010 & Cisse Faye et al., 2019 & $44-251$ \\
\hline
\end{tabular}


Table 10:

Summary results of groundwater quality data (all parameters are in aqueous form) used to test vulnerability assessments.

\begin{tabular}{ccccccc}
\hline Indicator & Unit & $\begin{array}{c}\text { N } \\
\text { (Samples) }\end{array}$ & Min & Max & Mean & Std Dev. \\
\hline DO & $\mathrm{mg} / \mathrm{L}$ & 40 & 3.5 & 10.3 & 6.4 & 1.5 \\
$\mathbf{N O}^{-}$ & $\mathrm{mg} / \mathrm{L}$ & 40 & 69 & 599 & 314 & 157 \\
TLF & $\mathrm{ppb}$ & 73 & 5 & 210 & 42 & 29 \\
$\mathbf{S O}_{4}{ }^{--}$ & $\mathrm{mg} / \mathrm{L}$ & 40 & 17 & 252 & 144 & 60 \\
$\mathbf{F e}$ & $\mathrm{mg} / \mathrm{L}$ & 28 & 0.002 & 1.032 & 0.135 & 0.225 \\
\hline
\end{tabular}

Table 11:

Statistics of the single parameter-sensitivity analysis

\begin{tabular}{ccccccc}
\hline Parameters & Default weight & $\begin{array}{c}\text { Default weight } \\
\text { \% }\end{array}$ & $\begin{array}{c}\text { effective } \\
\text { weight } \%\end{array}$ & Min & Max & SD \% \\
\hline D & 5 & $22 \%$ & $29 \%$ & $21 \%$ & $39 \%$ & $3 \%$ \\
R & 4 & $17 \%$ & $16 \%$ & $2 \%$ & $23 \%$ & $6 \%$ \\
A & 3 & $13 \%$ & $13 \%$ & $9 \%$ & $18 \%$ & $2 \%$ \\
S & 2 & $9 \%$ & $11 \%$ & $4 \%$ & $13 \%$ & $1 \%$ \\
T & 1 & $4 \%$ & $6 \%$ & $2 \%$ & $8 \%$ & $1 \%$ \\
I & 5 & $22 \%$ & $20 \%$ & $12 \%$ & $30 \%$ & $3 \%$ \\
C & 3 & $13 \%$ & $5 \%$ & $3 \%$ & $9 \%$ & $2 \%$ \\
\hline D & 5 & $18 \%$ & $23 \%$ & $16 \%$ & $27 \%$ & $2 \%$ \\
R & 4 & $14 \%$ & $13 \%$ & $1 \%$ & $17 \%$ & $5 \%$ \\
A & 3 & $11 \%$ & $9 \%$ & $6 \%$ & $12 \%$ & $1 \%$ \\
S & 2 & $7 \%$ & $8 \%$ & $2 \%$ & $9 \%$ & $1 \%$ \\
T & 1 & $4 \%$ & $4 \%$ & $1 \%$ & $5 \%$ & $1 \%$ \\
I & 5 & $18 \%$ & $15 \%$ & $9 \%$ & $22 \%$ & $2 \%$ \\
C & 3 & $11 \%$ & $4 \%$ & $2 \%$ & $6 \%$ & $2 \%$ \\
N & 5 & $18 \%$ & $24 \%$ & $21 \%$ & $27 \%$ & $1 \%$ \\
\hline S & 5 & $19 \%$ & $24 \%$ & $18 \%$ & $36 \%$ & $3 \%$ \\
I & 5 & $19 \%$ & $17 \%$ & $3 \%$ & $24 \%$ & $6 \%$ \\
N & 4 & $15 \%$ & $13 \%$ & $8 \%$ & $21 \%$ & $2 \%$ \\
T & 5 & $19 \%$ & $22 \%$ & $9 \%$ & $27 \%$ & $2 \%$ \\
A & 3 & $11 \%$ & $10 \%$ & $7 \%$ & $17 \%$ & $2 \%$ \\
C & 2 & $8 \%$ & $3 \%$ & $2 \%$ & $6 \%$ & $1 \%$ \\
S & 2 & $8 \%$ & $10 \%$ & $3 \%$ & $14 \%$ & $1 \%$ \\
\hline D & 0.186 & $19 \%$ & $23 \%$ & $16 \%$ & $33 \%$ & $2 \%$ \\
R & 0.212 & $21 \%$ & $18 \%$ & $3 \%$ & $27 \%$ & $6 \%$ \\
A & 0.259 & $26 \%$ & $23 \%$ & $16 \%$ & $35 \%$ & $3 \%$ \\
T & 0.121 & $12 \%$ & $13 \%$ & $6 \%$ & $21 \%$ & $2 \%$ \\
OS & 0.222 & $22 \%$ & $23 \%$ & $18 \%$ & $30 \%$ & $3 \%$ \\
\hline & & & & & & \\
\hline
\end{tabular}


Table 12:

Statistics of vulnerability degree in the DRASTIC, DRASTIC_N, SI and SINTACS methods

\begin{tabular}{ccccc}
\hline $\begin{array}{c}\text { Methods } \\
\text { Vulnerability degree }\end{array}$ & DRASTIC & DRASTIC_N & SI & SINTACS \\
\hline Moderate & $30 \%$ & - & $19 \%$ & $22 \%$ \\
High & $65 \%$ & $100 \%$ & $45 \%$ & $69 \%$ \\
Very high & $5 \%$ & - & $36 \%$ & $9 \%$ \\
\hline
\end{tabular}

